\title{
Application of the ELOHA Framework to Regulated Rivers in the Upper Tennessee River Basin: A Case Study
}

\author{
Ryan A. McManamay $\cdot$ Donald J. Orth • \\ Charles A. Dolloff · David C. Mathews
}

Received: 13 July 2011/Accepted: 4 April 2013/Published online: 28 April 2013

(C) Springer Science+Business Media New York 2013

\begin{abstract}
In order for habitat restoration in regulated rivers to be effective at large scales, broadly applicable frameworks are needed that provide measurable objectives and contexts for management. The Ecological Limits of Hydrologic Alteration (ELOHA) framework was created as a template to assess hydrologic alterations, develop relationships between altered streamflow and ecology, and establish environmental flow standards. We tested the utility of ELOHA in informing flow restoration applications for fish and riparian communities in regulated rivers in the Upper Tennessee River Basin (UTRB). We followed the steps of ELOHA to generate univariate relationships between altered flows and ecology within the UTRB. By comparison, we constructed multivariate models to determine improvements in predictive capacity with the addition of non-flow variables. We then determined whether those relationships could predict fish and riparian responses to
\end{abstract}

Electronic supplementary material The online version of this article (doi:10.1007/s00267-013-0055-3) contains supplementary material, which is available to authorized users.

R. A. McManamay ( $\square)$

Environmental Sciences Division, Oak Ridge National

Laboratory, Oak Ridge, TN 37831, USA

e-mail: mcmanamayra@ornl.gov

D. J. Orth

Department of Fish and Wildlife Conservation, Virginia Tech, Blacksburg, VA 24061, USA

C. A. Dolloff

USDA Forest Service, Department of Fish and Wildlife

Conservation, Virginia Tech, Blacksburg, VA 24061, USA

D. C. Mathews

Tennessee Valley Authority, 400 West Summit Hill Drive, Knoxville, TN 37902, USA flow restoration in the Cheoah River, a regulated system within the UTRB. Although ELOHA provided a robust template to construct hydrologic information and predict hydrology for ungaged locations, our results do not suggest that univariate relationships between flow and ecology (step 4, ELOHA process) can produce results sufficient to guide flow restoration in regulated rivers. After constructing multivariate models, we successfully developed predictive relationships between flow alterations and fish/ riparian responses. In accordance with model predictions, riparian encroachment displayed consistent decreases with increases in flow magnitude in the Cheoah River; however, fish richness did not increase as predicted 4 years after restoration. Our results suggest that altered temperature and substrate and the current disturbance regime may have reduced opportunities for fish species colonization. Our case study highlights the need for interdisciplinary science in defining environmental flows for regulated rivers and the need for adaptive management approaches once flows are restored.

Keywords Environmental flow - Water policy - Dams . Habitat restoration · Fish · Riparian

\section{Introduction}

The degradation of the world's freshwater habitats has led to global restoration efforts (Roni and others 2008). Successful restoration depends on developing appropriate endpoints while considering the context of each management situation (Roni and others 2002). Likewise, the development of appropriate goals depends on creating measurable and realistic objectives (Tear and others 2005). Frameworks are needed that provide broadly applicable, 
measurable objectives and contexts for restoration and management, especially in dam-regulated river systems.

According to Roni and others (2008), reestablishing a natural flow regime is considered one of the most successful process-driven approaches to restoration. However, the absence of quantitative, transferable relationships between anthropogenic alterations in flow and ecological responses (flow-ecology relationships) is a major limitation in developing broadly applicable environmental flow standards to inform water policy (Poff and others 2010; Poff and Zimmerman 2010). Predictive flow-ecology relationships should aid in prescribing the environmental flow needs of rivers with regulated or substantially altered flow. Based on the prevailing literature and our opinion, the Ecological Limits of Hydrologic Alteration (ELOHA) process is the most holistic regional framework for environmental flow management (Poff and others 2010; Richter and others 2012) (Fig. 1). In addition, it is the product of a consensus view of 19 international scientists and leaders in the field of environmental flow science (Poff and others 2010). Furthermore, the ELOHA framework has been applied in six states and three interstate river basins to determine environmental flow needs at the regional scale (Kendy and others 2012).

A common trend in the development of frameworks for broad-scale management is creating classification systems (Rosgen 1994; Poff 1996; Brandt 2000; Wehrly and others 2003; Wollock and others 2004; Sowa and others 2007).
Because classification systems consolidate variability, they provide a template to organize and generalize management actions at larger scales. The need for standardized flowecology relationships provided the motivation for creating flow classifications where streams are grouped according to similar hydrologic properties (e.g., Poff and Ward 1989; Poff 1996; Kennard and others 2010). Instead of developing management recommendations for every individual river, classes of rivers within a given region can be used to develop standards for managing flow needs (Poff 1996; Arthington and others 2006). These classes then provide a stratified approach to assess hydrologic alterations and flow-ecology relationships (Arthington and others 2006). The ELOHA framework is a classification-based process that includes four scientific steps: (1) building a hydrologic foundation of baseline hydrologic conditions and predicted natural hydrology, (2) classifying river types based on natural patterns in hydrology (along with potential geomorphic subclassification), (3) assessing flow alterations within each river class in relation to baseline conditions, and (4) determining flow-ecology relationships for each river class (Fig. 1). Flow-ecology relationships, as presented by Poff and others (2010), represent univariate relationships between a change in flow (e.g., low-flow duration) and an ecological response (e.g., fish richness). Changes in ecology and flow, many times represented as \% changes, are measured from natural or baseline conditions to the current or altered condition (Poff and others 2010;

\section{SCIENTIFIC PROCESS}

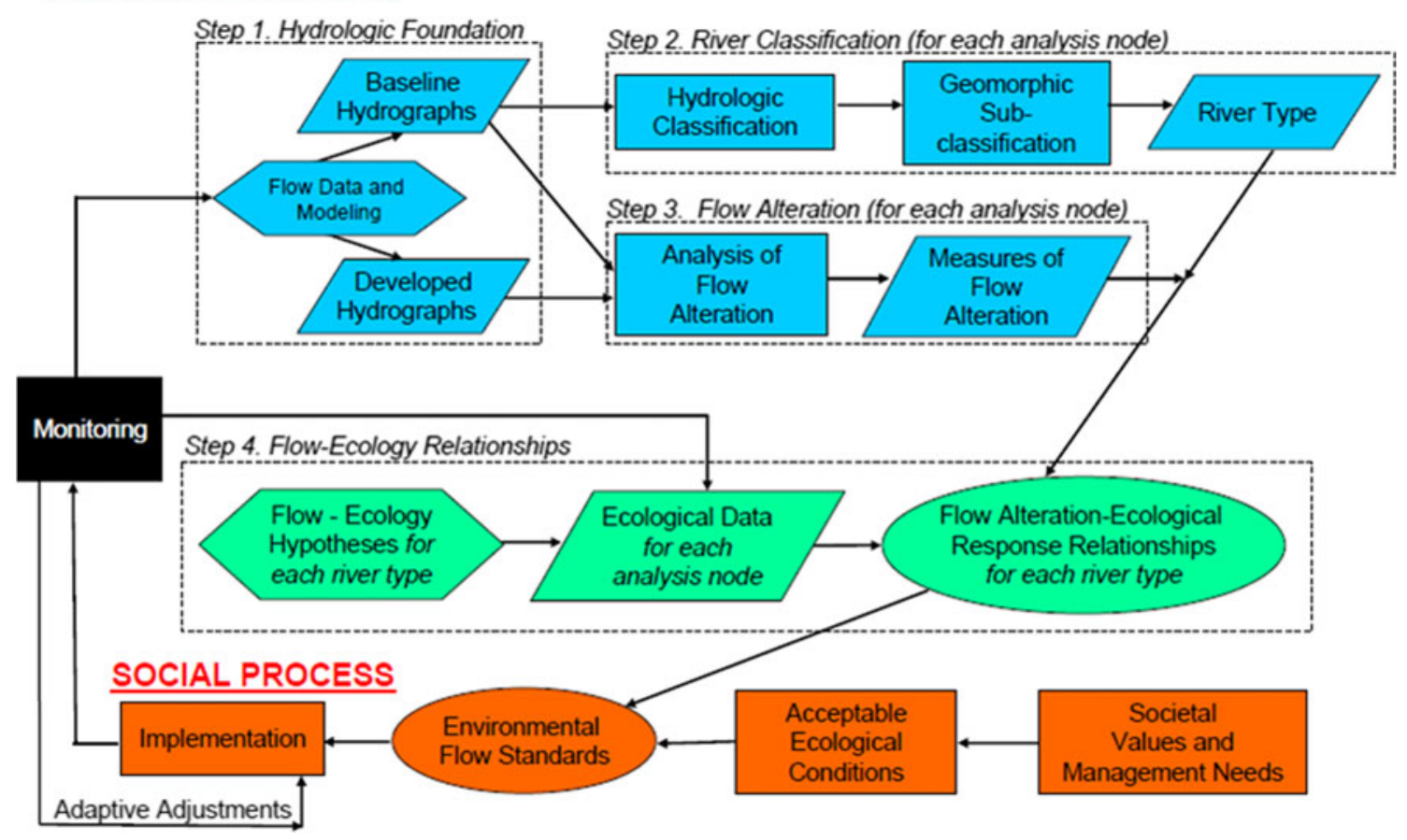

Fig. 1 The ELOHA framework (taken directly from Poff and others 2010) 
Poff and Zimmerman 2010). Flow-ecology relationships are compiled for many individual systems to create robust univariate relationships for a given region or flow class. These flow-ecology relationships are then used to inform social processes, such as defining acceptable ecological conditions based on changes in flow, i.e., "ecological limits," and instituting environmental flow policies (e.g., withdrawal thresholds). As flow policies are implemented, monitoring is used to make adaptive adjustments (Poff and others 2010). Although the ELOHA framework includes a potential geomorphic subunit classification (step 2), the only context for organizing flow-ecology relationships is hydrologic classes. Poff and others (2010) admit that other environmental variables (e.g., temperature) may confound relationships between flow and ecology; yet, the need to incorporate potentially confounding variables into flowecology relationships (e.g., via model building) is never explicitly stated.

Because of the use of ELOHA in multiple settings, we questioned its applicability in informing flow restoration within regulated river systems. In all areas of the globe, there has been heightened interest in either new dam construction (in less developed countries) or environmental flow assessment (in developed countries) (Tharme 2003). Reductions in flow variability have resulted in a loss of continentally distinct fluvial habitats across global scales (Poff and others 2007). With less than $2 \%$ of the US's rivers unregulated (Vitousek and others 1997), the opportunities for flow restoration below dams are quite common. Globally, there are over 800,000 dams (McCully 1996; Rosenberg and others 2000), with those numbers expected to dramatically increase in the coming decades (Richter 2011). In the US alone, there are over 85,000 dams (USACE 2011), 7,000 of which are $>15 \mathrm{~m}$ in height. The US has over 2,600 hydropower dams, $86 \%$ of which are privately owned (USACE 2011) and potentially subject to the Federal Energy Regulatory Commission (FERC 2006) relicensing procedures (reoccur on a 30-50-year rotation). Thus, frameworks to organize flow restoration applications below dams will continue to be a need for regulated river management.

The purpose of this study was to test the utility of the ELOHA framework in providing generalized flow-ecology relationships suitable for informing flow restoration applications in regulated rivers. We organize our study into two main objectives. First, we followed the ELOHA process to determine whether predictive univariate flow-ecology relationships could be developed for fish richness and riparian encroachment within regulated and unregulated systems of the Upper Tennessee River Basin (UTRB). We then determined the extent to which multivariate models could improve our ability to predict ecological responses to changes in flow. We focus on the UTRB because of its global importance as a region of diverse fish fauna (Abell and others 2008), and it has been an area of intense river regulation due to flood control, hydropower, and recreation (Etnier and Starnes 1993). Second, we use a case study to assess whether the predictive flow-ecology relationships, developed from the first objective, could be used to predict fish and riparian responses to flow restoration in the Cheoah River, a regulated system within the UTRB. We then discuss potential constraints of flow restoration in regulated river systems.

\section{Methods}

Part 1: The ELOHA Process (Steps 1-4)

\section{Develop Hydrologic Foundation}

The first two steps of the ELOHA process require assembling a hydrologic foundation and developing a flow classification. Flow classifications are advantageous in situations where pre-disturbance flow records are unavailable or insufficient to establish baseline conditions. For example, unregulated streams within a given flow class can be used to estimate hydrologic indices at ungaged or disturbed sites. Relationships between drainage area and flow can predict magnitude-related indices, whereas the central tendency or interquartile range (IQR) of values within a class can provide an estimate for hydrologic indices unrelated to drainage area (e.g., high-flow frequency, duration).

McManamay and others (2012b) developed a streamflow classification for an eight-state region of Southeastern US, including the UTRB. A majority of gages within the UTRB were classified as Stable High Baseflow (SHBF) streams. We selected 89 gages with $\geq 20$ years of unregulated or pre-dam regulation flow and the watersheds of which were predominately located within the Blue Ridge Physiographic province (Fig. 2) (Online Resource 1). We used the Hydrologic Index Tool (HIT) to calculate 171 hydrologic indices for each gage record (Henriksen and others 2006).

Using linear regression, we developed predictive relationships between 13 magnitude variables (log transformed) and drainage area (log transformed), i.e., flowdrainage area curves. One hydrologic index, baseflow index, could be calculated from other predicted hydrologic variables (=7-Day Low Flow/Mean Daily Flow). Two other hydrologic indices, constancy and predictability, were also related to drainage area, but in the non-linear form. We partitioned the data into three subsets and developed linear regressions between constancy and predictability and drainage area for each subset. For the remaining nine variables unrelated to drainage area, we 


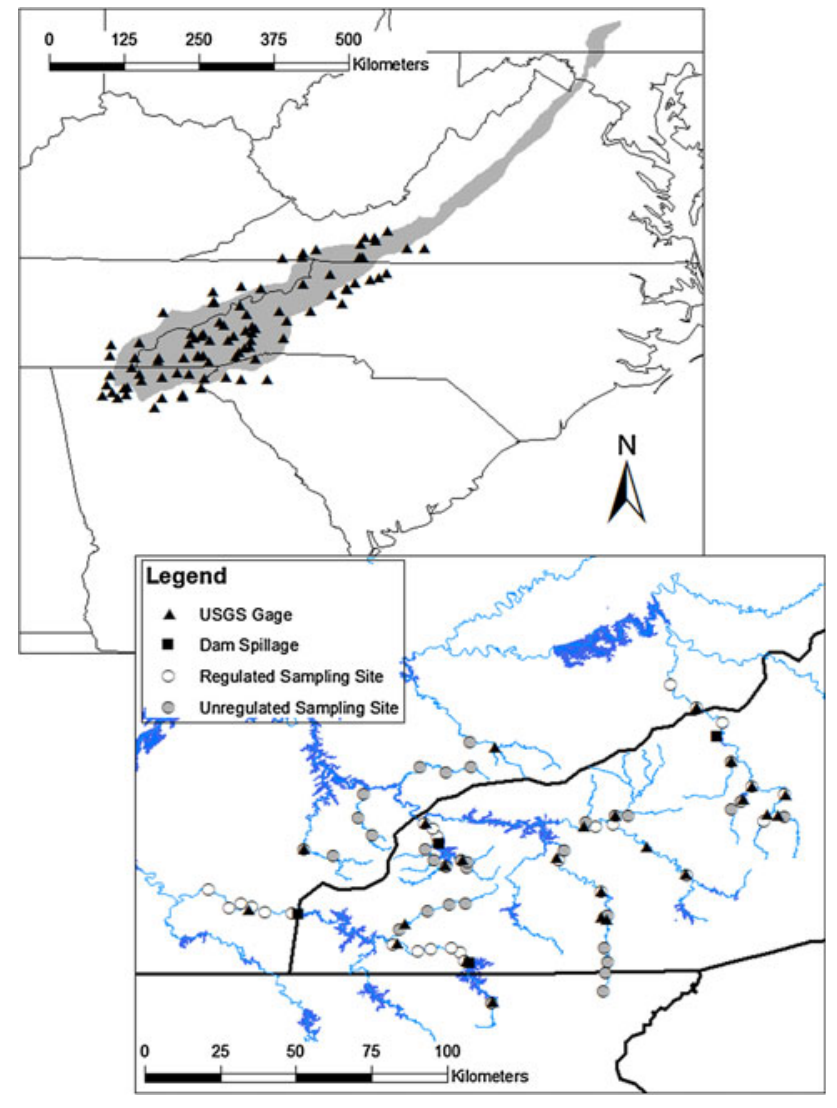

Fig. 2 a Map of USGS streamflow gages (top inset) in the SHBF class (McManamay and others 2012b) with a majority of their basins in the Blue Ridge Physiographic Province (shaded region). b Map of unregulated and regulated fish and riparian sampling sites and sources of flow record information (USGS gages and dam spillage) in the UTRB

calculated the mean and median values, standard deviation, and IQR.

\section{Develop Ecological Foundation}

Developing flow-ecology relationships (step 4 ELOHA) requires assembling unaltered hydrologic and ecological conditions from which responses can be measured. Regarding the fish community, we focus primarily on predicting fluvial species richness for unaltered sites since the number of species may increase predictably with drainage area within a given region. We then use those relationships to predict fluvial fish richness within regulated rivers.

We assembled fish community data from 34 unregulated and 27 regulated sampling sites in the UTRB collected by the Tennessee Valley Authority (TVA) $(n=54)$, Great Smokey Mountains National Park (GSMNP) $(n=3)$, and our own surveys $(n=4)$ (Fig. 2). Sites were located on the mainstem and tributaries of the Little Tennessee, Tuckasegee, Hiwasee, Pigeon, and Little River systems. Sites were located on wadeable streams in valleys with lower gradients rather than mountainous ridge creeks and streams. The drainage area ranged from 8.72 to $515 \mathrm{~km}^{2}$ in unregulated streams and $45.5-3,193 \mathrm{~km}^{2}$ in regulated streams. At most sites, the fish community were sampled within reaches 5-10 times the bankfull width, depending on the river size. Multiple gear types, including boat and backpack electroshockers, seines, and dip nets, were used to insure all habitat types represented were sampled (riffles, runs, pools, and shorelines). Sampling occurred during minimal flows to insure unbiased capture efficiencies. Sampling efforts continued in all habitat types until three successive runs failed to collect any new species. Generally, sampling efforts on the shoreline and channels of deep pools consisted of boatshocking in the downstream direction for 10-minute sampling efforts. Shallower habitats, such as riffles and runs, were sampled by holding a seine perpendicular to the current while one crew member backpack electrofished in a downstream direction toward the seine (one sampling effort). Backpack shocking was also conducted in an upstream direction along $45 \mathrm{~m}$ of shoreline (one sampling effort). In sluggish backwater and shallow pool habitats, seine hauls were made. Fish were collected, identified, and inspected for abnormalities. Juveniles were identified, but only adults were enumerated. All sites were sampled at least twice using similar methodology during 2000-2009. One exception was Abrams Creek where GSMNP employed 3-pass depletion methods on an annual basis using backpack electrofishing equipment, dip nets, and block nets. Given the small size of the creek, we presume little bias in fish species richness estimates for these sites.

We used the latest two sampling occasions for each site to estimate total richness per site. We used FishTraits (Frimpong and Angermeier 2009) to determine whether each species was fluvial depending on whether the species was endemic to the UTRB and preferred lotic habitats. Richness-drainage area relationships developed from smaller unregulated streams may overestimate fish richness for large regulated river systems. To avoid overestimation, we constructed lists of extant fish species for hypothetical sites located at the pour point of each of the major river basins in our study (Upper and Lower Little Tennessee, Tuckasegee, Hiwasee, and Pigeon). Species lists were generated using data from fish surveys, NatureServe (2010), Etnier and Starnes (1993), and Menhinick (1991). After compiling lists of fish species, we used FishTraits to select only fluvial species with a preference for systems larger than small streams. We then reviewed the lists for each pour point to insure assessments were as accurate as possible.

Predicting Fish Richness Using Models We hypothesized that drainage area, river fragmentation, gradient, and drainage basin unit would be important in determining fish richness. To calculate drainage area, we delineated the 
watersheds upstream of each site using 30-m digital-elevation models (DEMs) in ArcGIS version 9.3. River fragmentation was measured as the sum of the distance from the site upstream to the nearest dam (or, in the case of unregulated streams, upstream to the headwaters of the largest tributary) and downstream to the nearest dam. Gradient was measured over at least the entire reach distance $(5-10 \times$ width) with a transit and stadia rod. Fish assemblages in river systems transitioning from the BRPP into lower elevations seemed to be influenced by the neighboring Ridge and Valley Province. Because the precise location of province transition resembles a gradient rather than discrete location, we used elevation (DEM-derived) as a surrogate for any potential drainage unit effects on fluvial fish richness. All variables were measured similarly at the pour point of each of the major river basins. We constructed generalized linear models in the R programming environment to predict fluvial fish richness as a Poisson distribution. Drainage area was log transformed to avoid overestimating richness at sites with smaller basins. We included all combinations of variables to determine the best model using Akaike's Information Criterion (AIC), where the lowest AIC scores indicate the most parsimonious model with the highest explanatory power (Burnham and Anderson 2004).

Riparian Assessment We did not develop an ecological baseline for riparian communities in regulated systems due to a lack of sufficient data and knowledge of the pre-regulation riparian condition. However, we assessed the riparian community's current condition at each fish sampling location by evaluating the coverage of riparian vegetation within the bankfull channel. At each fish sampling location, we established four transects perpendicular to the current in locations representative of various habitats within each reach (Bisson and others 2006). Along each transect, we measured bankfull according to Harrelson and others (1994). Riparian coverage was measured as the total width of woody riparian vegetation outcrops within the bankfull channel. Typically, these areas either extended from the bankfull margin into the channel or were present as instream islands. In larger, heavily braided river systems (such as diversions), field assessments could be difficult; thus, aerial photographs and on-the-ground photos were used to supplement riparian coverage estimates. Because flows were partially restored in the Cheoah River, we used on-the-ground assessments in combination with aerial photos to estimate pre-restoration riparian coverage. We calculated riparian coverage as a percent of bankfull width.

\section{Assemble Overlapping Flow and Ecological Data}

Assessing spatial flow-ecology relationships requires isolating biological sampling locations that also include flow information. However, overlapping hydrologic and ecological information within regions is typically limiting and may fail to maximize existing data (Knight and others 2008). With regard to available flow information, fish and riparian sampling locations fell into one of three categories: (1) Sampling location has a proximate USGS gage or dam with a 20-year record within the reach of interest (i.e., within 10 times the bankfull width and not influenced by tributary inflow), (2) sampling location has a mainstem gage or dam with an active 20-year record not located within the reach, or (3) sampling location does not have any active flow information on mainstem (11 unregulated sites).

For Category 2, we assembled data from the last 20 years from the nearest mainstream gage or nearest upstream dam. Typically, the source of flow record information was less than $5 \mathrm{~km}$ from the site. Discharge data from the dams were supplied by TVA, Alcoa Power, and Progress Energy on request. Based on the difference in drainage area between the gage and sampling location, we used flow-drainage area curves ("Develop Hydrologic Foundation" section) and the daily hydrologic record for the nearest-neighboring unregulated gage to account for incoming flows and adjust each hydrologic record. We calculated indices for each modified hydrologic record using HIT. For Category 3, we used flow-drainage area curves to predict magnitude-related hydrologic indices weighted by values from the nearest-neighboring gage. For non-magnitude indices, we used values from the nearestneighboring gage as estimates. Non-flow magnitude indices, such as high-flow frequency, from gaged sites are typically used to predict values for ungaged locations (Ries and Crouse 2002). In addition, non-magnitude indices tend to be have low dispersal around the central tendency within the SHBF Class (e.g., mean (SD) high-flow frequency $=14.45(1.94), n=89)$.

\section{Flow-Ecology Assessment}

Flow-ecology relationships can be exhibited as \% changes in flow and \% ecological responses on $\mathrm{x}$ and $\mathrm{y}$ axes, respectively (Poff and others 2010). We predicted unregulated hydrologic indices using linear regression (magnitude-related indices) or using median values from the SHBF class (non-magnitude indices) ("Develop Hydrologic Foundation" section) (Online Resource 1). We calculated \% hydrologic alteration by comparing actual hydrologic values to predicted values. We predicted fish richness at regulated sites using glm models and calculated $\%$ ecological responses. For riparian responses, we used the $\%$ riparian coverage in the channel. We plotted flowecology relationships for all regulated sites according to different dam operation types. For fish richness, we used $\%$ 
changes in 90-day low flow, 1-day maximum flow, highflow frequency, constancy, and the number of reversals because these variables tend to be heavily influenced by dam regulation in the region (McManamay and others 2012a). The 90-day low flow and 1-day high flow are the annual minimum and maximum values of mean discharge computed over 90 consecutive days and one day, respectively. High-flow frequency is the number of annual occurrences of flows surpassing the 25th percentile flow magnitude (mean daily flow exceeded $25 \%$ of the time). Constancy is a measure of temporal invariance (see Colwell 1974). Reversals are the annual number of negative and positive changes in flow from one day to the next. For riparian coverage, we used 90-day low flow, 1-day maximum flow, high-flow frequency, and high-flow duration for the same reasons mentioned above. High-flow duration is the mean number of days a $>25$ th percentile flow remains above that threshold. We also calculated a hydrologic alteration index as the square root of the sum of squares for $\%$ hydrologic alterations for all indices.

Based on site visitation, internet searches, and data from National Inventory of Dams (USACE 2011), we categorized sites into dam operation types according to the operations of the nearest upstream dam. Run-of-river and storage dams typically have little impact on hydrology since they harness hydroelectric energy based solely on incoming flows. Peaking dams have greater hydrologic impacts since they store and release water in pulses to maximize energy. Sites influenced by diversion projects were located within river reaches the flows of which were diverted downstream for power production.

Univariate flow-ecology relationships may be misleading since they do not account for other potentially confounding variables (Poff and others 2010). In contrast, model building can estimate the effect of hydrologic indices on ecological responses in relation to non-flow variables. Using data from all sites, we constructed generalized linear mixed models (GLMM) in the R programming environment to predict fluvial fish richness and $\%$ riparian coverage as Poisson and binomial distributions, respectively. Due to the availability of flow information, only 55 of the 61 sites sampled were included. Models were constructed using the glmm function in the repeated package (Lindsey 2012), which calculates a random intercept using a normal mixing distribution calculated by the Gauss-Hermite quadrature (Lindsey 2012). Like glm, glmm not only uses maximum likelihood to estimate parameters but also includes identifying a nesting variable as the random effect (random intercept). Although located on separate reaches, multiple sampling locations on the same river system constitute repeated sampling. We used 8-digit HUCs as a random effect to account for any evolutionarily derived effects on fish richness or any unobvious basin-specific effects on riparian coverage. Using the same hydrologic indices above, we constructed models to predict fluvial fish richness and riparian coverage. We included dam operation type, gradient, and elevation as fixed effects for predicting fish and riparian responses. Fragmentation was used as a predictor in fish richness models. Preliminary inspection of the data suggested that the volume of water carried by regulated systems had higher explanatory power than basin size; thus, drainage area was excluded from fish richness models. In riparian coverage models, we excluded fragmentation, but included drainage area. Larger systems in the UTRB have more naturally braided channels; thus, drainage area may have residual effects on riparian conditions in regulated systems. We used AIC values to determine the best models and to examine the relative importance of flow variables in relation to other variables. We also compared the coefficients of hydrologic indices and other factors across models to determine relative effect sizes and determine any generalized trends.

\section{Part 2: Case Study}

In the previous section, we followed the ELOHA framework to produce generalized flow-ecology relationships to inform environmental flow management in regulated streams in the UTRB. Extensive flow restoration efforts and ecological monitoring in the Cheoah River provided an opportunity to examine whether flow-ecology trends, if produced, could be used to predict ecological responses to restoration. Based on flow-ecology relationships from Part 1 , we hypothesized how flow restoration influenced ecology in the Cheoah River separately and in combination with uncontrolled events (e.g., floods). We used a series of quantitative and qualitative assessments of pre-post comparisons in hydrology, fish ecology, and riparian ecology to identify predicted or unpredicted responses to flow restoration. In addition, pre-post comparisons of temperature and substrate were used to provide evidence of indirect influences of flow restoration on ecology.

\section{Study Site Description and Background}

The Cheoah River is located in western North Carolina within the Appalachian Mountains of the Southeastern U.S.A (Fig. 3). The river drains a $550 \mathrm{~km}^{2}$ predominately forested watershed located within the Nantahala National Forest. The area generally receives $150-230 \mathrm{~cm}$ of precipitation annually. High mountain ridges and steep terrain (30\% relief) can cause relatively high rates of erosion, which contributes to thin soil cover and limits crop agriculture in some areas. The river falls from $533 \mathrm{~m}$ right below the dam to less than $335 \mathrm{~m}$ over its length (slope 
Fig. 3 Map of the Cheoah River, a regulated tributary of the Little Tennessee River system in Graham County, North Carolina. Inset major stream reaches are stratified by segments. Points represent locations of stream channel photographs and pebble counts

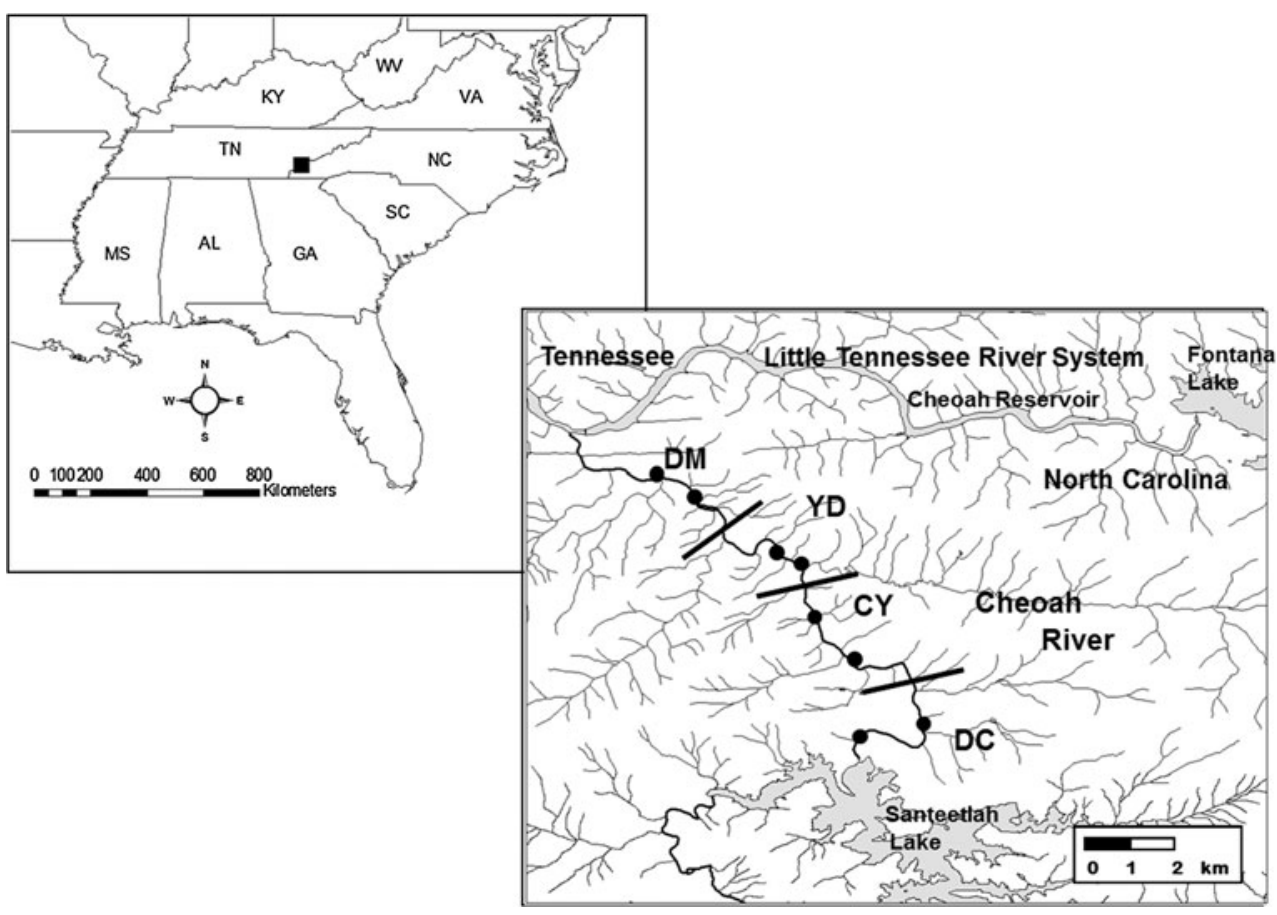

$\sim 1.3 \%$ ). In general, the river channel is constrained by its valley, underlying bedrock, and high embankment from the road, which lead to very little lateral migration. The upper $3.2 \mathrm{~km}$ has a relatively low gradient $(0.3-0.6 \%)$, whereas the lower $11.6 \mathrm{~km}$ has a steeper gradient (1-2\%).

The Cheoah River is impounded by Santeetlah Lake, a $456-\mathrm{km}^{2}$ reservoir, and flows into Calderwood Reservoir on the Little Tennessee River System. Following the construction of the Santeetlah Dam in 1927, over $95 \%$ of incoming flow was diverted to Cheoah Powerhouse, bypassing $14.8 \mathrm{~km}$ of the Cheoah River. Flows were limited to leakage from the dam $\left(<0.002 \mathrm{~m}^{3} \mathrm{~s}^{-1}\right)$, inputs from tributaries, and occasional large pulses $\left(>24 \mathrm{~m}^{3} \mathrm{~s}^{-1}\right)$ from the reservoir (Fig. 4). Because of surface release operations, sediment supply was cut off from entering the Cheoah River with the exception of tributary inputs. Although gravel and cobble substrates tend to increase with distance from the dam, the streambed throughout the Cheoah River is very coarse and sediment starved (McManamay and others 2010). Riparian vegetation encroachment and high gradient intensified sediment-starved conditions (Normandeau and others 2002a). Altered hydrology and sediment supply led to degraded habitat for many aquatic biota, including the federally protected plant, Virginia spiraea (Spiraea virginiana), and the federally endangered Appalachian elktoe (Alasmidonta raveneliana) (USFWS 1994). The Cheoah River may have had over 40 fish species prior to impoundment (D. A. Etnier, University of Tennessee, personal communication). Currently, the Cheoah River has only 19 species of fish.
Starting in 1999, FERC initiated the relicensing process, which resulted in a collaborative research effort among multiple agencies to assess existing habitat conditions and make recommendations for environmental flows and substrate augmentation (Normandeau and others 2002a; R2 2003; Dilts and others 2003). Indicators of Hydrologic Alteration (IHA) (Richter and others 1996) as well as Instream Flow Incremental Methodologies (IFIM) were used to identify ecological flow needs. Based on scientific findings and a round table discussion, FERC issued the new 40-year license in effect from March 1, 2005, requiring Alcoa Power to establish seasonally variable base flows between 1.13 and $2.83 \mathrm{~m}^{3} \mathrm{~s}^{-1}$ and periodic high-flow events $\left(28.32 \mathrm{~m}^{3} \mathrm{~s}^{-1}\right.$ ) (FERC 2005) (Fig. 4). In addition, Conservation Fisheries Inc. propagated and reintroduced wounded darters (Etheostoma vulneratum) and spotfin chub (Cyprinella monacha) into the Cheoah River and monitored their status (Rakes and others 1999; Petty and others 2011).

\section{Hydrology}

Our first objective was to determine whether flow restoration in the Cheoah River produced hydrology similar to baseline conditions, i.e., that of the SHBF Class. We assembled dam spill data and USGS daily flow records for the lower Cheoah River (USGS 0351706800) from 1999 to the present. We constructed hydrologic records for the four reaches of the Cheoah River (Fig. 3) by accounting for tributary inflow, discharge at the USGS gage, and dam 

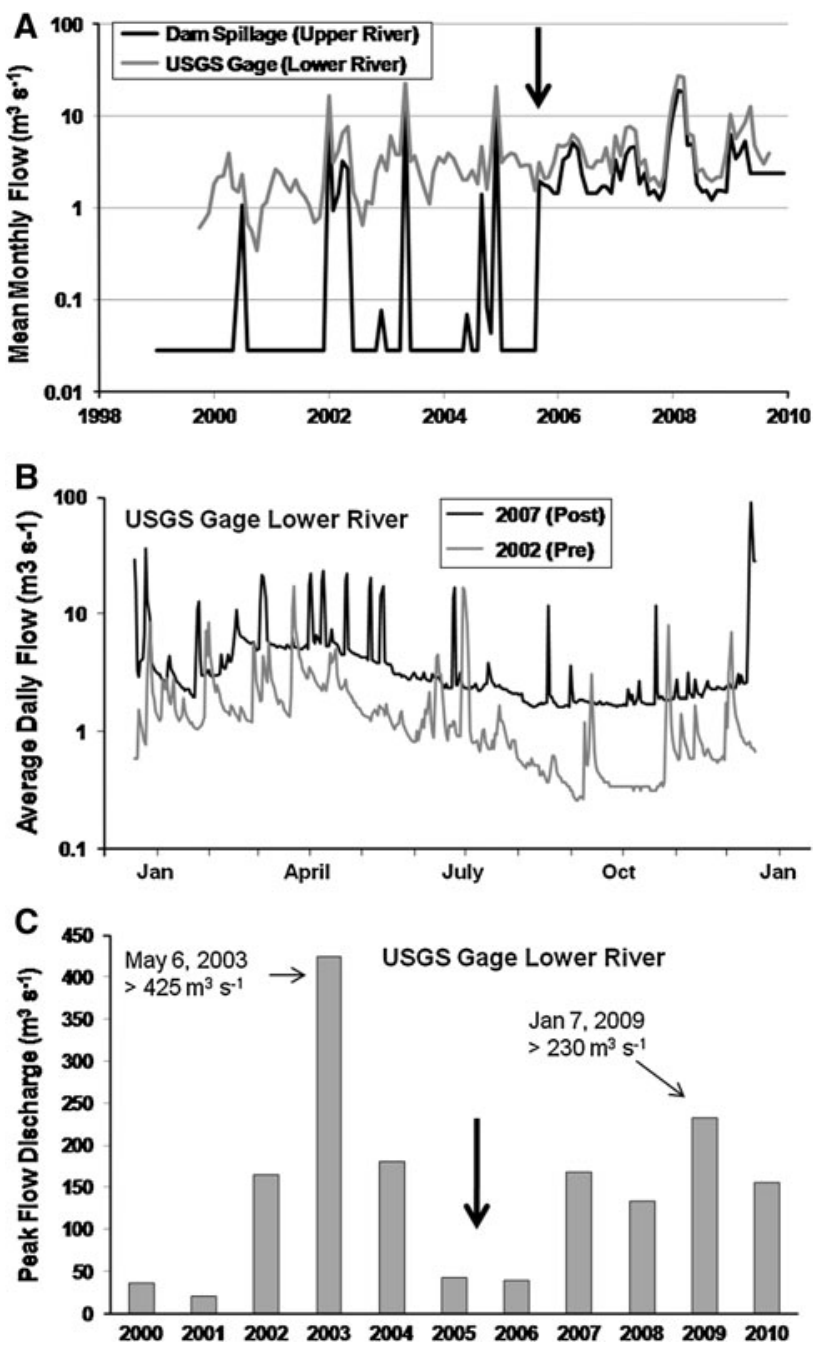

Fig. 4 a Mean monthly dam spillage and discharge at the USGS gage in the lower Cheoah River. Differences in magnitudes reflect tributary inflow. b Average daily flow for a typical year before (2002) and after (2007) the initiation of the new flow regime. c Peak flow discharges from 1999 to 2010 at the USGS gage on the Cheoah River. Arrows indicate the initiation of the new FERC-mandated flow regime in graphs $\mathrm{A}$ and $\mathrm{C}$

spillage. We divided each hydrologic record into two datasets: pre-flow restoration (1999-2005) and post-flow restoration (2005-2010). Pre- and post-restoration data were imported into HIT and 171 indices were calculated. Magnitude variables in our dataset were standardized by drainage area. We used a permutational multivariate analysis of variance (PMANOVA) in the adonis function in $\mathrm{R}$ (vegan package) (Stevens and Okasanen 2012) to test for significance of all hydrologic indices simultaneously among pre-restoration, post-restoration, and the SHBF class datasets. PMANOVA is a non-parametric version of MANOVA except that it uses metric distance matrices to partition sums-of-squares and large permutations to develop pseudo-F statistics and determine significance
(Anderson 2001; Stevens and Okasanen 2012). We used Euclidean distances and 100 permutations to develop $\mathrm{F}$ ratios. For each individual hydrologic index, we conducted Kruskal-Wallis ranked sum tests followed by multiple comparison tests (kruskalmc function, pgirmess package) in R (Giraudox 2012).

\section{Fish Ecology}

We predicted that increases in seasonal base flows and small flood frequencies would increase fish species richness. We determined fish assemblage responses to flow restoration by (1) assessing changes in fluvial fish species richness and 2) evaluating trends in occupancy for dominant fluvial fish species. Fish assemblage monitoring was conducted sporadically in the Cheoah River from 1993 to 2003 and then on an annual basis from 2004 to 2009. Sampling methods ranged from 3-pass depletion electrofishing (1993-2003), Index of Biotic Integrity (IBI) electrofishing (Karr 1981; Karr and others 1986) (2004-2005), snorkeling (2006), and a combination of snorkeling and IBI approaches (2008-2009). We examined all potential recolonists as fluvial species not currently residing in the river, but could colonize from tributaries, downstream (Calderwood Reservoir), or introduction from Santeetlah Reservoir. Potential recolonists were defined as species (1) not captured for more than one year within the mainstem and/or (2) represented by only one individual if captured. We sampled tributaries directly feeding the mainstem Cheoah River and above Santeetlah Dam using IBI electrofishing methods. Calderwood Reservoir was sampled using boat electrofishing IBI methods (Normandeau and others 2002b). We assembled latitude and longitude coordinates of fish presence/absence information (1993-2009) from agency personnel and our field surveys. Mesohabitats, or areas of similar geomorphology, were delineated for the entire Cheoah River using aerial imagery and sub-foot resolution Light Detection and Ranging (LIDAR). Because mesohabitats represent areas of similar morphology and habitat, they provided a framework to calculate patch occupancy (the proportion of sites occupied by a species).

Although occupancy provides an approach to utilize the presence/absence data, elucidating patterns in species occupancy requires accounting for detection probability (p), i.e., the probability of detecting a species, given its presence (MacKenzie and others 2006). In order to account for variation in occupancy due to sampling methods, we used multiple sampling occasions in 2009 as well as the literature to estimate method-specific $P$ for each of the 11 fish species. In 2009, we snorkeled in 41 sites three times followed by an IBI electrofishing approach in a subset of sites. The length of reach sampled for each site ranged from 15-105 m and was proportional to mesohabitat size. Snorkeling was 
conducted at each site by splitting the entire wetted margin into three lanes and assigning one diver to each lane. Searching pace was altered depending on depth, water clarity, and habitat complexity. Divers would call species, abundances, and approximate sizes to a recorder on the stream bank. IBI electrofishing was conducted in shallower depths (mean, $1 \mathrm{~m}$ ) with backpack units and seines and similar methods to that described for TVA sampling. Detection histories for fish species were used in PRESENCE (USGS 2012) to estimate $P$ for snorkeling and IBI methods separately and together, thereby providing $P$ estimates for 2004-2009. Peoples and Frimpong (2009) reported average $P$ values for fish species collected via 3-pass depletion at 316 fish sampling sites across the US. Thus, we were able to estimate $P$ for species collected during 1993-2003. For each species and each sampling year, we simulated 10 adjusted occupancy estimates in GENPRES (USGS 2012) based on the number of sites sampled, proportion of sites occupied, and estimated p. Using simulated values, we conducted a two-way PMANOVA to test for changes in occupancy due to flow restoration and flooding for all species simultaneously. We tested for pre- and post-changes for each individual species using two-way permutational analysis of variance (PANOVA). Coefficients from the model were used as indicators of increases or decreases in occupancy for each species.

\section{Riparian Ecology}

Theoretically, the restoration of flood magnitudes and base flows should reestablish active channel maintenance, such as habitat formation and removing encroaching vegetation (Barinaga 1996; Poff and others 1997; Trush and others 2000). We used a series of pre-post photographs taken in July 2001 and July 2008 at established benchmarks to monitor changes in riparian coverage due to flow restoration and flooding. In 2001, photographs of the river channel were taken from benchmarks established during IFIM studies (Normandeau and others 2002a). Each benchmark was marked with a latitude/longitude coordinate and a metal post. We returned to a subset of benchmarks that could be accurately identified and photographed the river channel (Fig. 3).

As a follow-up approach, we surveyed the entire river course seasonally from January 2008 to July 2009 for signs of overturned islands of alder vegetation within the wetted channel. The majority of the river was accessible and visible from the road; however, in areas of poor visibility, we waded through the channel or walked the bank. We documented any overturned island with a latitude/longitude coordinate and a photograph. Vegetated island overturn between 2008 and 2009 was visually inspected in relation to flooding magnitudes.

\section{Temperature and Substrate}

Changes in a river's flow regime influence the thermal buffering capacity of the channel, which translates into altered stream temperatures (Caissie 2006). We provide pre- and post-flow restoration comparisons of water temperatures to determine potential effects of additional flow volume and surface release operations on the thermal regime in the Cheoah River. Prior to the reregulation of flows in 2001, 19 temperature loggers were placed throughout the Cheoah River basin to determine the effect of surface release operations on temperatures in the lower river (Normandeau and others 2001). Fifteen temperature loggers were placed in tributaries above Santeetlah Reservoir and four were placed in the Cheoah River below the dam. We assessed the preexisting temperature regime by comparing average daily water temperatures to elevation and Julian day of year. Using data from the Cheoah River USGS gage (0351706800), we compared the average monthly temperatures (for all year) and the average summer temperatures (June-September) for the pre-relicensing agreement (1999-2005) and post-relicensing agreement (2006-2010) using a Kruskal-Wallis ranked sum test.

We investigated whether the changes in flow induced changes in the size distribution of stream bed sediments. We predicted that textural fining could occur by two mechanisms: (1) The removal of vegetation outcrops could mobilize sediments and (2) the inundation of new stream margins could increase sediments via erosive processes. One hundred pebble counts were conducted along IFIM transects (Fig. 3) in 2002 during bedload transport field studies according to the Wolman (1954) method (R2 2003). In 2008, we returned to the benchmarks and repeated the pebble counts using the same methods. We compared the median particle size $\left(\mathrm{D}_{50}\right)$ and size distribution of particles along each transect for the pre- and post-flow restoration periods using a KruskalWallis test.

\section{Results}

\section{Part 1: ELOHA Process}

\section{Hydrologic Foundation}

The variance explained by predictive linear regressions for the 13 magnitude variables ranged from 89.4 to $92.6 \%$, all of which were highly significant $(P<0.0001)$ (Online Material 1). The variance explained by our non-linear models for constancy and predictability was 70.1 and $64.8 \%$, respectively. The IQR and standard deviations for the remaining nine non-magnitude variables were low and indicative of small variation (Online Material 1). 


\section{Ecological Foundation}

Fish assemblage sampling from the latest two sampling occasions at 61 sites in the UTRB resulted in 109 fish species, 84 of which were fluvial fishes. A total of 143 extant fish species, 110 of which were fluvial fishes, were estimated to potentially occur within all of the major river basins in our study. The number of fluvial fishes within each basin ranged from 35 to 77 , whereas the actual number of species we estimated that might actually exist at the pour point of each basin ranged from 34 to 75 species. The best glm model (lowest AIC score) for predicted fluvial fish richness included drainage area (log transformed), gradient, and elevation and explained $94.0 \%$ of the variance (Table 1; Fig. 5a). Most regulated sites had lower fish richness values than predicted (Fig. 5b). All coefficients in the best model were significant (Table 1). Drainage area had positive effects on richness values, whereas gradient and elevation had negative effects. Riparian coverage for unregulated sites averaged $2.95 \%$ and ranged from 0 to $15.3 \%$. Riparian coverage for regulated sites averaged $21.9 \%$ and ranged from 0 to $79.6 \%$, with the highest values found at sites impacted by diversion dams.

\section{Assemble Overlapping Flow and Ecological Data}

Out of 61 total sampling sites in the UTRB, 55 sites had sufficient flow data as proximate USGS gages, dam spillage, or from estimation using predictive hydrologic foundation information. Twenty-three of the 55 sites had a proximate USGS gage or dam with spillage information on the mainstem reach of interest (Fig. 2). Twenty of the 55 sites had USGS gage or dam spillage information on the mainstem not proximately located, the values of which were adjusted to accommodate differences in incoming flow. The remaining ungaged locations $(n=11)$ were all unregulated sites with nearby unregulated USGS locations, the hydrologic index values of which were predicted as described in the "Methods" section.

Table 1 Results of the best generalized linear model predicting fluvial fish richness at 38 unregulated sites in the UTRB

\begin{tabular}{lclcr}
\hline Variable & Estimate & SE & $Z$ value & \multicolumn{1}{c}{$P$} \\
\hline Intercept & 2.906 & 0.305 & 9.539 & $<0.0001$ \\
$\log$ (drainage area) & 0.158 & 0.040 & 3.978 & 0.0001 \\
Gradient & -0.261 & 0.092 & -2.850 & 0.0044 \\
Elevation & -0.001 & 0.000 & -4.710 & $<0.0001$ \\
Null deviance & 298.4 & DF & 38 & \\
Residual deviance & 25.47 & DF & 34 & \\
\hline
\end{tabular}

The best model was selected as having the lowest AIC value (Burnham and Anderson 2004). Coefficient estimates, standard error (SE), and Ward's $Z$ values are provided for each variable
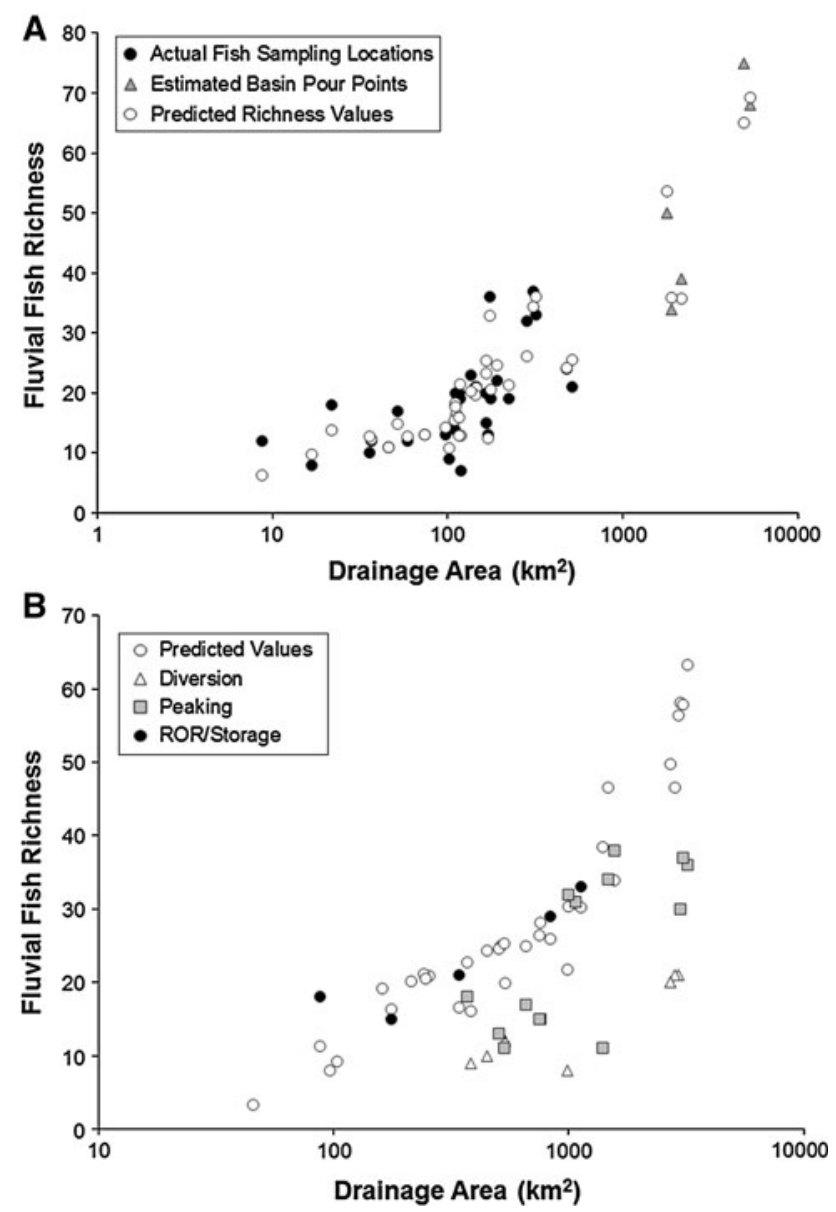

Fig. 5 a Fish richness values from actual sampling at unregulated sites, estimated values from 8-digit Hydrologic Unit Code pour points, and predicted values using a generalized linear model (Table 1). b Fish richness values from actual sampling at regulated sites and predicted values using generalized linear model

\section{Flow-Ecology Assessment}

Some relationships emerged when visualizing $x-y$ plots of $\%$ hydrologic change versus \% ecological response. However, much of the variation in ecological patterns was due to dam operation types (Fig. 6, Online Material 2). Fish richness responses were predominately negative for all diversions and a majority of peaking dams; however, changes in fish richness were positive or near zero for run-of-river and storage dams (Fig. 6, Online Material 2). Diversion dams tended to have substantial decreases in 90-day low flow and 1-day maximum flow, but had little effect on the number of reversals. Peaking dams tended to increase the 90-day low flow and the number of reversals. All dams, except run-ofriver and storage dams, tended to decrease the 1-day maximum flow and constancy. Percent changes in fish richness displayed stronger positive correlations with 1-day high flows and constancy and a negative correlation with the hydrologic alteration index (Fig. 6, Online Material 2). 
Fish Richness
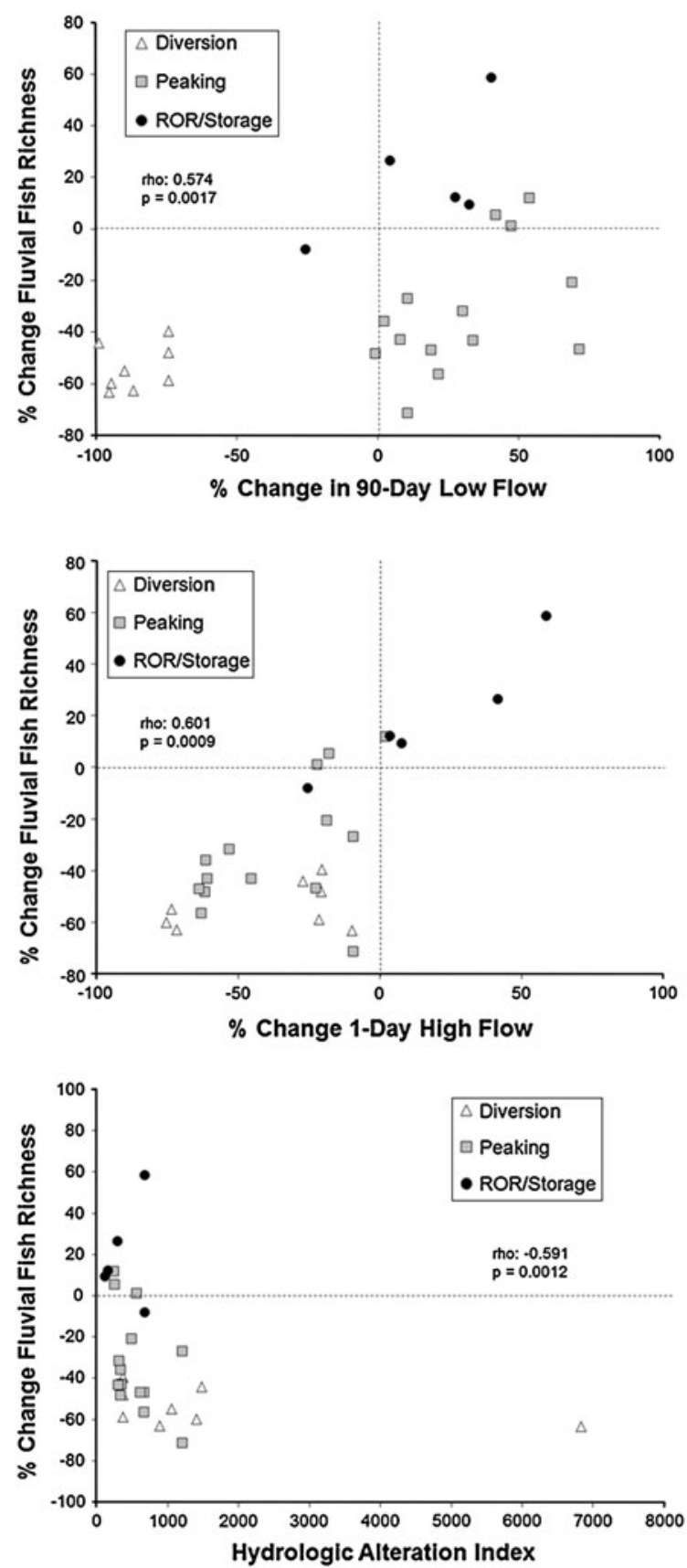

Fig. 6 Relationships between altered hydrology and ecological responses for regulated sampling sites only. Percent changes were calculated as existing conditions from the predicted baseline.

Similar to fish richness responses, most variation in \% riparian coverage was attributed to dam operation types, with diversion dams having the highest values. Riparian coverage displayed a negative and positive correlation with 90-day low flow and the HA index, respectively (Fig. 6). No patterns were observed for riparian response to 1-day maximum flow, flood frequency, or the duration of highflow events.
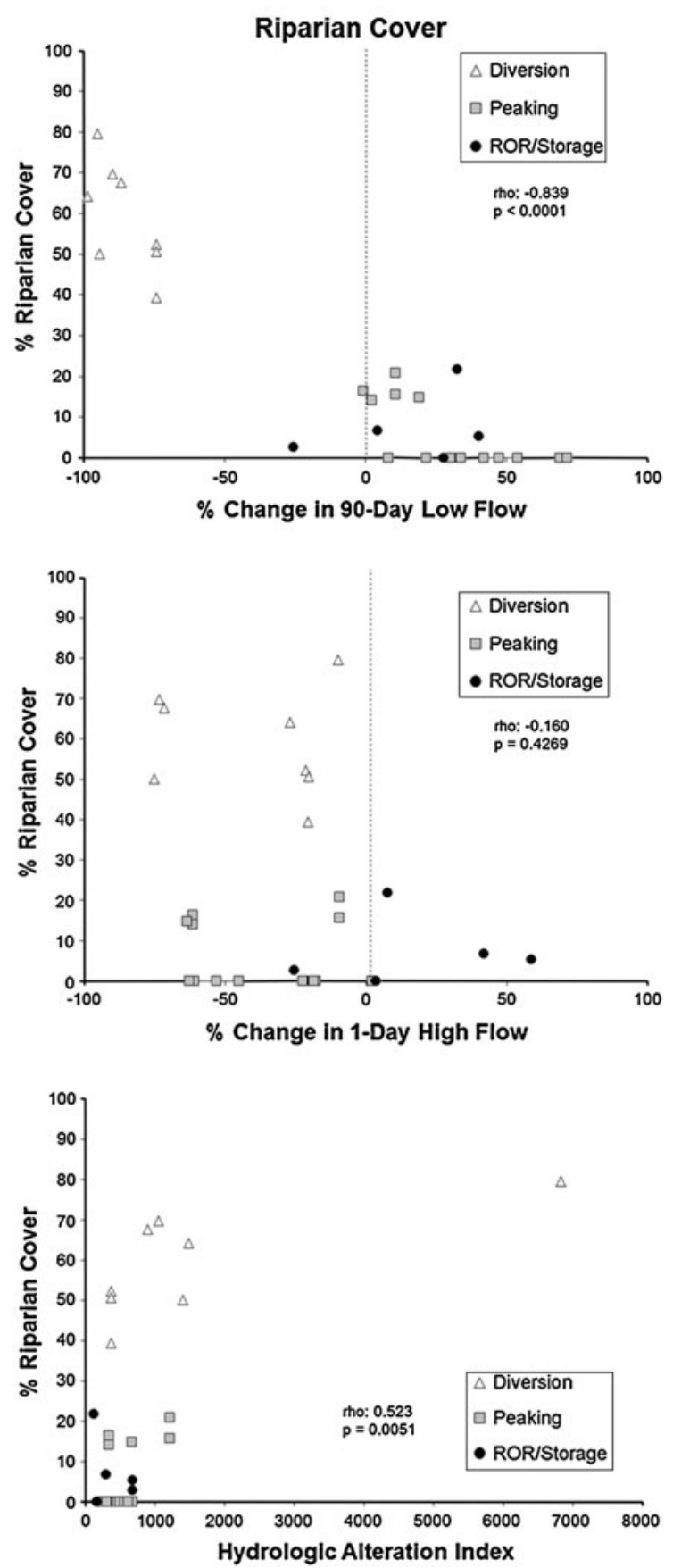

Spearman's rho and significance for rank correlations are provided. (See "Methods" section for predicting baseline hydrology and ecology)

Multivariate models explained substantially more variation than univariate (flow only) models. For example, fish richness and riparian coverage did not display a consistent pattern relative to the 90-day low flow; however, data predicted from the best models trended well with observed data (fish richness: $R^{2}=0.77$; riparian coverage: $R^{2}=0.93$; Fig. 7a, b, respectively). Deviation and AIC values in all models decreased with the inclusion 

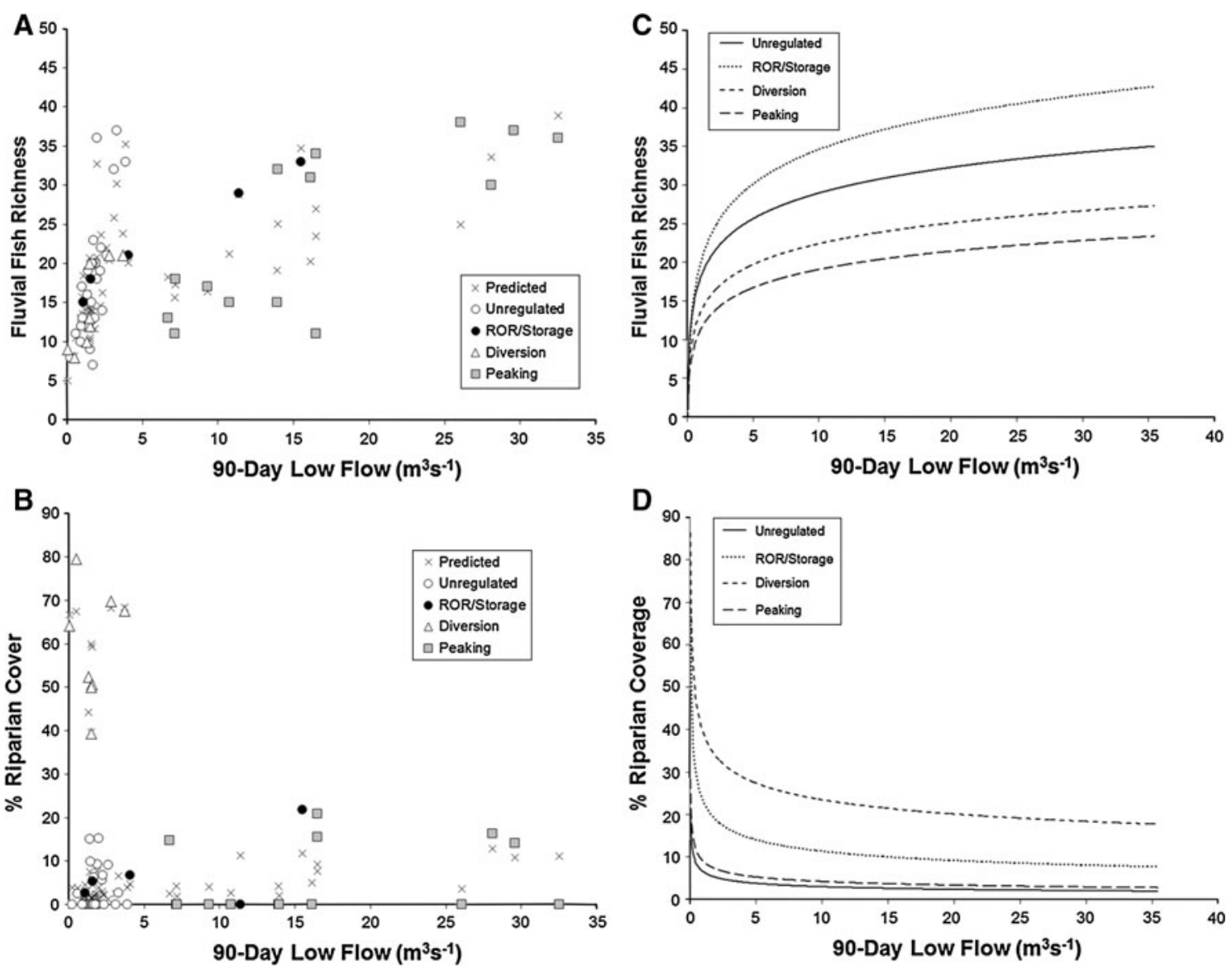

Fig. 7 Relationships between 90-day low flow and a actual values for fish richness, b actual values for \% riparian cover, c simulated values for fish richness, and $\mathbf{d}$ simulated values for $\%$ riparian cover according to different dam operation types. Simulations were developed using the best models developed for fish richness and \%

of non-flow variables. For fish richness, dam operation types, gradient, and elevation explained the majority of variation in most models (Table 2), whereas hydrologic variables tended to explain less variation. An exception was 1-day high flow, which had the highest explanatory power in its respective model. Diversion and peaking dams typically had negative effects on fluvial fish richness and coefficient estimates were significant in a majority of models (Online Material 3). Run-of-river and storage projects had positive effects on fish richness, but were significant in three of the models. Gradient and elevation had consistent and significant negative effects on fish richness (Online Material 3). Although fragmentation (fragment length) explained relatively low amounts of variation in fish richness, coefficients were typically positive and significant in three models. Random effects were present in three of the five fish richness models, suggesting some variation attributed to basins (Table 2). All hydrologic indices were present in the best models

riparian cover in relation to 90-day low flows (Tables 2, 4). Data were simulated by varying the 90-day low flow and dam operation types while keeping all other variables constant; thus, simulations are not shown for predictive accuracy, but as an example of the utility in hypotheses generation from model construction

and all indices had significant coefficients with the exception of high-flow frequency (Table 3). The 90-day low flow, 1-day maximum flow, and constancy had positive effects on fish richness, whereas the number of reversals and high-flow frequency had negative effects.

For riparian coverage models, dam operation types, gradient, and elevation typically explained the majority of variation (Table 4). Riparian coverage was poorly related to Diversion, and run-of-river/storage dams displayed significant positive effects, elevation displayed significant negative effects, and gradient displayed positive effects on riparian coverage (Online Material 3). Drainage area was present in three of the four best models predicting riparian coverage (Table 4). All hydrologic indices were present in the best models (Table 4) and all indices had significant coefficients with the exception of high-flow frequency (Table 3). The 90-day low flow and high-flow duration had negative effects, whereas 1-day high flow and high-flow frequency had positive effects. 
Table 2 Generalized linear mixed models predicting fluvial fish richness using different hydrologic indices and non-flow variables

\begin{tabular}{|c|c|c|c|c|}
\hline Model & N. par & Deviance & LogLike & AIC \\
\hline \multicolumn{5}{|l|}{ 90-day low flow } \\
\hline $\begin{array}{l}\text { Dam-Op-Type }+ \text { elevation }+ \text { gradient }+\log (90 \text {-day low flow })+\text { random } \\
\text { effect[basin }]+ \text { fragmentation }\end{array}$ & 9 & 50.07 & -155.0 & 328.0 \\
\hline Dam-Op-Type + 90-day low flow & 5 & 92.85 & -176.4 & 362.8 \\
\hline $\log (90$-day low flow) & 2 & 122.1 & -191.0 & 386.1 \\
\hline \multicolumn{5}{|l|}{ 1-day high flow } \\
\hline $\log (1$-day high flow $)+$ Dam-Op-Type + gradient + elevation + random effect[basin $]$ & 8 & 43.02 & -151.5 & 319.0 \\
\hline $\log (1$-day high flow $)+$ Dam-Op-Type & 5 & 79.64 & -169.8 & 349.6 \\
\hline $\log (1$-day high flow) & 2 & 124.0 & -192.0 & 388.0 \\
\hline \multicolumn{5}{|l|}{ High-flow frequency 1} \\
\hline Gradient + Dam-Op-Type + elevation + fragmentation + high-flow frequency 1 & 8 & 58.29 & -159.1 & 334.2 \\
\hline Gradient + high-flow frequency 1 & 3 & 101.8 & -180.8 & 367.7 \\
\hline High-flow frequency 1 & 2 & 182.5 & -221.2 & 446.4 \\
\hline \multicolumn{5}{|l|}{ Constancy } \\
\hline Dam-Op-Type + elevation + gradient + fragmentation + constancy + random effect[basin] & 9 & 50.22 & -155.1 & 328.2 \\
\hline Dam-Op-Type + constancy & 5 & 141.0 & -200.5 & 411.0 \\
\hline Constancy & 2 & 144.1 & -202.0 & 408.1 \\
\hline \multicolumn{5}{|l|}{ Reversals } \\
\hline Dam-Op-Type + gradient + elevation + fragmentation + reversals & 8 & 53.06 & -156.5 & 329.0 \\
\hline Dam-Op-Type + reversals & 5 & 171.4 & -215.7 & 441.4 \\
\hline Reversals & 2 & 200.0 & -229.9 & 463.9 \\
\hline
\end{tabular}

For each hydrologic index, models are presented in order of hydrologic index only (bottom), hydrologic index and strongest predictor variable (middle), and the best model (top). For each model, variables are presented in order of explanatory power from left to right. Deviance represents the residual variation. The best models were selected as having the lowest AIC value (Burnham and Anderson 2004)

Part 2: Case Study

\section{Hydrology}

Hydrologic variables were significantly different among pre- and post-restoration periods and the SHBF class (Permutational MANOVA, $F=8.68, P=0.005$ ). Twenty one of the 26 hydrologic indices were significantly different among pre- and post-flow restoration periods and the SHBF class (Kruskal-Wallis, Fig. 8). Typically, post-flow restoration values were more similar to the SHBF class than pre-flow restoration values. Post-flow restoration values for mean daily flow, daily variation (CV), baseflow index, high-flow frequency 1, low-flow duration indices, constancy, and rise/fall rates had values similar to the SHBF class compared to pre-restoration values. However, post-restoration values for low-flow frequency, high-flow frequencies 1 and 2, and high-flow duration were less similar than pre-restoration values.

\section{Fish Ecology}

Over a 17-year period, 11-18 fish species were found at any given time within eight yearly sampling occasions (July-August) (Appendix Table 7). The number of mesohabitats sampled per year increased over time with the highest amounts occurring from 2006 to 2009. The number of fluvial fish species collected per year ranged from 9 to 13, with the highest values in 2008 and 2009 (Appendix Table 7), which coincided with higher sampling effort and dual methodologies. Despite increases in search efforts, all species found during the post-flow restoration period had been found in the Cheoah River at least once prior to 2006. Of the eight potential fluvial recolonists, only black redhorse established permanent residency in the river. The black redhorse species was found once in 1993 and not again until 2006, following the flow restoration. We could not conclude that longnose dace established permanent residency since only one individual was captured during sampling events in 2005, 2008, and 2009 in the same location adjacent to the mouth of a tributary. Blacknose dace, mottled sculpin, creek chub, and white sucker had the potential to colonize directly from either tributaries feeding the mainstem Cheoah River or Calderwood Reservoir. Redbreast sunfish and Tennessee shiner are currently found in tributaries above Santeetlah Dam.

Nine species showed declines in occupancy following the 2003 flood event (Table 5), six of which were significant. One species, central stoneroller, was not found in the river until 2003, after which it displayed significant 
Table 3 Coefficient estimates, SE, and Ward's $Z$ value for hydrologic variables taken from the best models predicting fluvial fish richness and \% riparian cover

\begin{tabular}{|c|c|c|c|c|c|}
\hline Response & Variables & Estimate & SE & $Z$ value & $P$ \\
\hline \multirow[t]{5}{*}{$\begin{array}{l}\text { Fish } \\
\text { richness }\end{array}$} & $\begin{array}{l}\log (90 \text {-day low } \\
\text { flow) }\end{array}$ & 0.201 & 0.065 & 3.102 & 0.0019 \\
\hline & $\begin{array}{l}\log (1 \text {-day high } \\
\text { flow })\end{array}$ & 0.334 & 0.063 & 5.294 & $<0.0001$ \\
\hline & $\begin{array}{l}\text { High-flow } \\
\text { frequency } 1\end{array}$ & -0.017 & 0.009 & -1.818 & 0.0691 \\
\hline & Constancy & 2.006 & 0.653 & 3.073 & 0.0021 \\
\hline & Reversals & -0.013 & 0.004 & -2.873 & 0.0041 \\
\hline \multirow[t]{4}{*}{$\begin{array}{l}\text { Riparian } \\
\text { cover }\end{array}$} & $\begin{array}{l}\log (90 \text {-day low } \\
\text { flow })\end{array}$ & -0.355 & 0.087 & -4.064 & $<0.0001$ \\
\hline & $\begin{array}{l}\log (1-\text { day high } \\
\text { flow })\end{array}$ & 0.418 & 0.129 & 3.241 & 0.0012 \\
\hline & $\begin{array}{l}\text { High-flow } \\
\text { frequency } 1\end{array}$ & 0.035 & 0.020 & 1.711 & 0.0870 \\
\hline & $\begin{array}{l}\text { High-flow } \\
\text { duration }\end{array}$ & -0.099 & 0.050 & -1.983 & 0.0474 \\
\hline
\end{tabular}

The best models were selected as having lowest AIC value (Burnham and Anderson 2004)

increases. Flow restoration had negative effects on seven species, five of which were significant (Table 5). Three species (whitetail shiner, smallmouth bass, and central stoneroller) showed significant increases following flow restoration. Black redhorse occupancy increased following flow restoration; however, changes were not significant.

\section{Riparian Ecology}

Comparisons of ground photographs in 2001 and 2008 suggested that large decreases in riparian vegetation, primarily alder (Alnus glutinosa), occurred within the channel following flooding and flow restoration (Fig. 9). Following our survey of the entire river course, we observed a majority of overturned islands of alder vegetation during January 2009 following a $232-\mathrm{m}^{3} \mathrm{~s}^{-1}$ flood (Fig. 10). Prior to this time, we had observed very little breakup of encroached riparian vegetation despite some floods exceeding $170 \mathrm{~m}^{3} \mathrm{~s}^{-1}$. A majority of overturned islands were observed in the upper $2 \mathrm{~km}$ of the river near Santeetlah Dam.

\section{Temperature and Substrate}

Based on pre-flow restoration data, temperature increased linearly with decreases in elevation within the Cheoah River basin above Santeetlah Dam. Directly below Santeetlah Dam, temperature displayed a non-linear increase, especially evident in summer (Fig. 11). Comparisons of average monthly temperatures were not significantly different between pre- and post-flow restoration periods when considering all months $\left(X^{2}=1.3125, P=0.2519\right)$; however, average summer monthly temperatures were significantly higher following the flow restoration $\left(X^{2}=7.8766\right.$, $P=0.0050$ ). Only four of the eight transects showed significant changes in particle size distributions (Table 6). Within the first $9.5 \mathrm{~km}$ from the dam downstream, $\mathrm{D}_{50}$ displayed decreases following flow restoration; however, increases in $\mathrm{D}_{50}$ were observed after $11 \mathrm{~km}$ from the dam.

\section{Discussion}

We followed the first four steps of the ELOHA process to generate flow-ecology relationships and inform environmental flow management in regulated rivers. Our results do not support the assertion that univariate relationships between flow and ecology can produce results sufficient to guide management in regulated rivers. However, after constructing multivariate models, we were able to successfully develop predictive relationships between flow and ecology. These relationships can inform management by providing standards to guide flow restoration and predict ecological responses to restoration. For example, multivariate models can provide tools to simulate ecological responses to changes in flow by controlling for multiple confounding variables (e.g., Fig. 7c, d).

Despite extensive flow restoration efforts, we observed minimal responses from the fish community in the Cheoah River four years post-restoration. Patterns in the fish occupancy suggested that a majority of species were recovering from a peak flood event, which may have masked any changes due to flow restoration. Degraded habitats (e.g., temperature, sediment) and extensive basin fragmentation, in conjunction with peak flooding, may have reduced opportunities for new species colonization. In contrast to fish, the riparian community showed consistent responses to changes in the flow regime as predicted. Given the temporal resolution of our riparian data, we were unable to distinguish between any flood or flow restoration effects. Nonetheless, major reductions in riparian vegetation suggested that increased flow magnitudes had reestablished active channel maintenance.

\section{Part 1: ELOHA Process}

\section{Hydrologic Foundation}

Strengths of the ELOHA process include providing a template to organize hydrologic information, predicting hydrology and stratifying flow-ecology relationships. Since the response of rivers to a disturbance may be dependent upon their preexisting natural flow regime (McManamay and others 2012a), flow classes provide a 
Table 4 Generalized linear mixed models predicting \% riparian cover using different hydrologic indices and non-flow variables

\begin{tabular}{|c|c|c|c|c|}
\hline Model & $\begin{array}{l}\text { N. } \\
\text { par }\end{array}$ & Deviance & logLike & AIC \\
\hline \multicolumn{5}{|l|}{ 90-day low flow } \\
\hline $\begin{array}{l}\text { Dam-Op-Type }+ \text { elevation }+ \text { gradient }+\log (90 \text {-day low flow })+\log (\text { drainage area })+\text { random } \\
\text { effect[basin] }\end{array}$ & 9 & 364.3 & -239.1 & 496.3 \\
\hline Dam-Op-Type +90 -day low flow & 5 & 471.5 & -292.7 & 595.5 \\
\hline $\log (90$-day low flow) & 2 & 1,709 & -911.5 & 1,827 \\
\hline \multicolumn{5}{|l|}{ 1-day high flow } \\
\hline Dam-Op-Type + gradient + elevation $+\log (1$-day high flow $)+$ random effect[basin] & 8 & 376.2 & -245.1 & 506.2 \\
\hline Dam-Op-Type + 1-day high flow & 5 & 423.0 & -268.5 & 546.9 \\
\hline Log(1-Day High Flow) & 2 & 1,595 & -854.7 & 1,713 \\
\hline \multicolumn{5}{|l|}{ High-flow frequency 1} \\
\hline $\begin{array}{l}\text { Dam-Op-Type }+ \text { gradient }+ \text { elevation }+\log (\text { drainage area })+\text { random effect }[\text { basin }]+\text { high-flow } \\
\text { frequency } 1\end{array}$ & 9 & 378.3 & -246.1 & 510.2 \\
\hline Dam-op-type + high-flow frequency 1 & 5 & 454.8 & -284.4 & 578.8 \\
\hline High-flow frequency 1 & 2 & 1,857 & -985.3 & 1,975 \\
\hline \multicolumn{5}{|l|}{ High-flow duration } \\
\hline $\begin{array}{l}\text { Dam-Op-Type }+ \text { gradient }+ \text { elevation }+\log (\text { drainage area })+\text { high-flow duration }+ \text { random } \\
\text { effect[basin] }\end{array}$ & 9 & 377.2 & -245.6 & 509.1 \\
\hline Dam-Op-Type + high-flow duration & 5 & 464.7 & -289.3 & 588.6 \\
\hline High-flow duration & 2 & 1,809 & -961.3 & 1,927 \\
\hline
\end{tabular}

For each hydrologic index, models are presented in order of hydrologic index only (bottom), hydrologic index and strongest predictor variable (middle), and the best model (top). For each model, variables are presented in order of explanatory power from left to right. Deviance represents the residual variation. The best models were selected as having the lowest AIC value (Burnham and Anderson 2004)

stratified approach to assess hydrologic alterations (Arthington and others 2006; Poff and others 2010). In addition, environmental flow standards and policies for regions can be based upon class membership rather than defining baselines for each individual river. Flow-drainage area curves and IQRs for the SHBF class proved useful in constructing hydrologic information for sampling sites lacking adequate flow information. Only $42 \%$ fish sampling sites within our study had flow record information within the reach of interest, which is fairly high compared to other studies (e.g., $11 \%$ in Knight and others 2008). We were able to strengthen our analysis (i.e., sample size) by adjusting hydrologic records or predicting hydrologic indices for the remaining sampling locations using the hydrologic foundation.

\section{Ecological Baseline and Flow-Ecology Assessment}

A critical step in the ELOHA framework is developing flow-ecology relationships, which form the basis for water policy management. Poff and others (2010) indicate that these relationships can vary according to ecological responses, specific hydrologic indices, particular flow classes, and the degree of hydrologic alteration. Although the authors suggest that the shape (e.g., linear versus non-linear) of ecological response curves could vary, flow-ecology relationships are univariate comparisons between changes in flow and changes in ecology from baseline conditions. There are two critical issues that arise from these methods that we argue may not lead to meaningful relationships. First, Poff and others (2010) suggest that scientific uncertainty exists in the form of confounding factors, such as temperature and geomorphology, and may play a role in defining flow-ecology relationships. The authors go on to suggest that this scientific uncertainty should be incorporated as an element of risk in stakeholder discussions and consensus decision making regarding flow needs. We argue that scientific uncertainty should be incorporated into models that explicitly test and control for confounding variables. In addition, results of multivariate models are intuitive, create new hypotheses, generate simulated responses (e.g., Fig. 7c, d), and can be used to inform stakeholder involvement.

The second critical issue is that of developing baseline ecological conditions. In order to estimate baseline fish richness for regulated sites, we constructed linear models based on data from unregulated streams. One major limitation in this approach was determining fish richness for very large river systems, in which baseline information is rare. Species-area relationships are complicated by granularity (spatial resolution) (Palmer and White 1994) and habitat complexity (Angermeier and Schlosser 1989). 

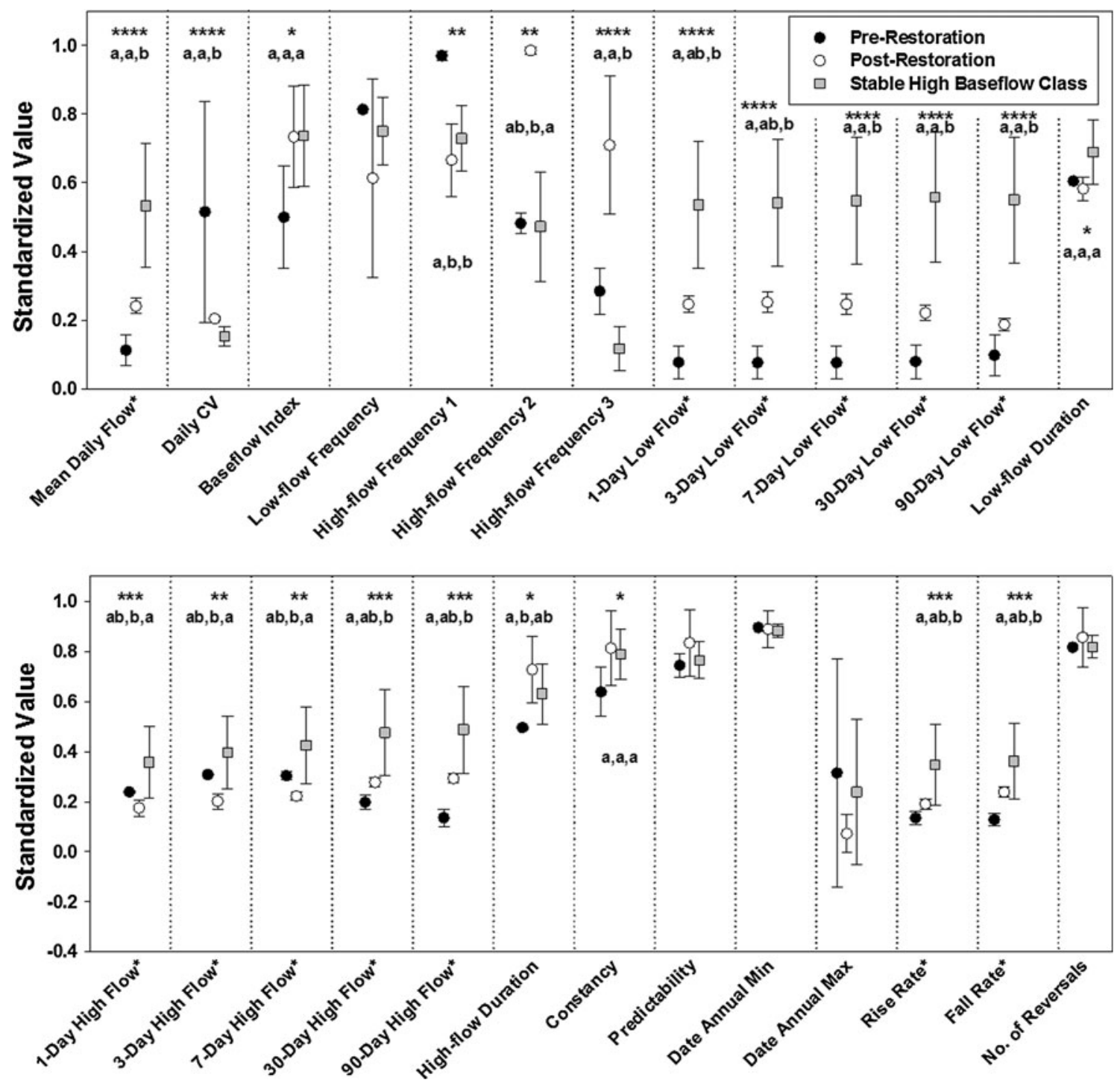

Fig. 8 Mean values of 26 hydrologic variables calculated for the pre(1999-2005) and post-flow restoration (2005-2010) periods in the Cheoah River and for 86 streams in the SHBF class (McManamay and others 2012b). Error bars represent 1 standard deviation. Different

We suspect that these issues are intensified in situations where species richness values must be estimated to generate species-area curves, as in the case of our analysis. Reconstructing baseline ecological conditions may be extremely difficult for systems that are rarely, if ever, sampled and have been regulated for many decades. However, the most robust inferences in management can be produced from pre-post analyses or comparisons of altered/ unaltered conditions (Stewart-Oaten and others 1986; Underwood 1994). Thus, developing hydrologic and ecological baseline conditions for regulated systems should be an active area of future research.

Our development of GLMM models, as well as simple $x-y$ plots, revealed the importance of other factors besides letters represent statistical significance between groups at the $P=0.05$ level (Kruskal-Wallis post-hoc comparisons). $*, * *, * * * * * * *$ represent statistical significance at the $P=0.05$, $0.01,0.001$, and 0.0001 levels, respectively

flow in determining ecological responses. One limitation is that we did not include interactions among variables. Because small sample sizes may preclude the inclusion of high numbers of parameters, an alternative approach is hierarchical linear modeling, which has shown success in providing structure to flow-ecology relationships (McCargo and Peterson 2010). We suspect that temperature would have played a role in predicting fish richness had it been included in our models; however, the availability of temperature data was limiting. We attempted to control for unsampled predictors by organizing sites into various dam operation categories, which may have consistent simultaneous effects on multiple variables. Fish richness was considerably lower in diversion and peaking dams than 
Table 5 Trends in occupancy estimates of 11 species collected from 1993 to 2009 within the Cheoah River

\begin{tabular}{|c|c|c|c|c|c|c|c|c|c|c|}
\hline Species & 1993 & 1999 & 2003 & 2004 & 2005 & 2006 & 2008 & 2009 & Flood & Flow Restoration \\
\hline Whitetail shiner & $\boldsymbol{\theta}$ & 0 & ○ & $\boldsymbol{0}$ & $\boldsymbol{0}$ & ○ & ○ & 0 & -0.016 & 0.074 \\
\hline River chub & ○ & - & $\bullet$ & 0 & $\bullet$ & ○ & 0 & 0 & -0.005 & -0.060 \\
\hline Smallmouth bass & 0 & 0 & $\bullet$ & - & - & 0 & $\bullet$ & 0 & -0.180 & 0.171 \\
\hline Warpaint shiner & (1) & 0 & $\bullet$ & - & $\bullet$ & $\bullet$ & 0 & 0 & 0.038 & -0.005 \\
\hline Rock bass & 0 & 0 & $\bullet$ & - & - & (1) & - & $\boldsymbol{\theta}$ & -0.123 & -0.084 \\
\hline Greenfin darter & 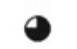 & 0 & - & (1) & (1) & (1) & - & (1) & -0.134 & -0.053 \\
\hline Tangerine darter & ( & ( & $\bullet$ & C & (1) & C & (1) & C & -0.221 & -0.017 \\
\hline Northern hog sucker & ( & C & - & ( & c) & - & ( ) & (1) & -0.004 & -0.041 \\
\hline Tuckasegee darter & ( & 0 & - & c & c & 0 & 0 & 0 & -0.134 & -0.053 \\
\hline Central stoneroller & 0 & 0 & C) & C & c) & C & c) & C & 0.072 & 0.001 \\
\hline Black redhorse & (1) & 0 & 0 & 0 & 0 & (1) & C) & 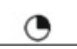 & -0.075 & 0.056 \\
\hline
\end{tabular}

$>0.9 \bigcirc 0.6-0.9 \bigcirc 0.3-0.6 \bigcirc 0.1-0.3 \bigcirc<0.1 \bigcirc$

Occupancy estimates were adjusted for differences in detection probability using the program GENPRES. Values on right represent coefficients from Permutational Multivariate Analysis of Variance (PMANOVA) indicating responses to flooding or flow restoration.

Numbers in bold represent significant effects of each treatment for individual species from PANOVA

unregulated systems of similar flow magnitude. Surprisingly, run-of-river and storage dams had higher fluvial fish species than unregulated systems; however, we suspect this is an artifact of sites within our dataset and not general conditions in the UTRB. Sites downstream of storage dams included locations along the Pigeon River, which seemed unaffected by Lake Logan, a small headwater impoundment. Sites on the Little Tennessee River $(n=2)$ below Emory Dam, a run-of-river hydroelectric facility, were minimally affected by subdaily flow fluctuations and had multiple migratory species, such as redhorse, and a high diversity of benthic fishes. Gradient and elevation had the most consistent and largest effects on patterns in fish richness than other variables. Gradient controls the relationship between with flow and habitat formation (Gordon and others 2004) and may limit the migratory potential of many stream fishes. In the UTRB, temperature, conductivity, and stream productivity all decrease with elevation, potentially explaining the relationship with fish richness. Lastly, habitat connectivity and its relation to reach-scale processes may ultimately determine the ability of many species to persist (Fausch and others 2002; Dieterman and Galat 2004; Reid and others 2008). We predicted basin fragmentation would be among the strongest predictors of fluvial species richness in the UTRB; however, the effects were only significant in three of the five fish richness models.

Similar to fish richness, riparian coverage models were influenced largely by dam operation, all of which exhibited positive effects. The highest values for riparian coverage were below diversion projects in relation to massive losses in water volume. Intuitively, we expected riparian coverage would be more extensive in lower-gradient systems; however, our models suggested the opposite. One explanation is that riparian coverage may be more prone to expansion in higher-gradient systems following hydrologic changes since floodplains are more confined.

Part 2: Case Study

\section{Hydrology}

Following flow restoration, hydrologic conditions within the Cheoah River were more similar to that of unregulated streams in the SHBF class and were assumed to be more suitable to fish recolonization and riparian removal. However, determining whether conditions were favorable to ecological restoration is somewhat uncertain. For example, due to scheduled rafting events, the frequency of smaller-magnitude floods increased; however, the magnitude of peak flooding decreased. It is important to note that flood frequencies are calculated with respect to median flow conditions (e.g., frequency of flows $3 \times$ median flow); thus, if median flows and flooding frequencies change simultaneously, interpreting hydrologic variables can be difficult. 
Fig. 9 Serial photographs of riparian vegetation in the Cheoah River channel taken pre-(2001) and post-(2009) changes in the flow regime. Changes in flow include the occurrence of a major flood in 2003 and flow restoration in 2005. 2001 photographs taken from Normandeau and others (2002a)
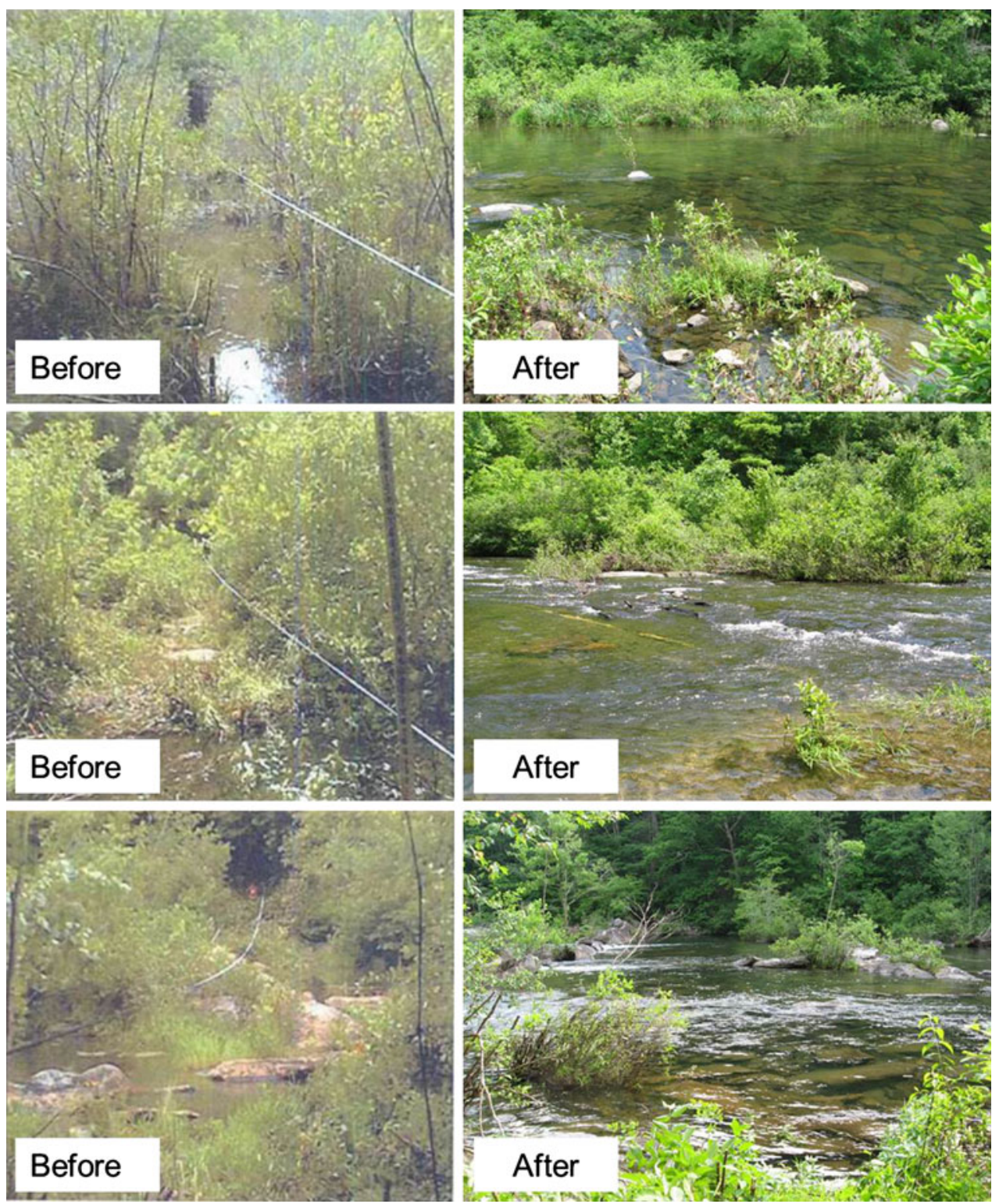

\section{Fish Ecology}

According to our species richness-drainage area model (Table 1; Fig. 5) the Cheoah River should have 8-14 more species than it does currently, depending on the reach. Following flow restoration, the 90-day low flow increased from 0.05 to $1.54 \mathrm{~m}^{3} \mathrm{~s}^{-1}$ in the upper reach below the dam and from 1.54 to $2.59 \mathrm{~m}^{3} \mathrm{~s}^{-1}$ in the lower most reach. Based on our multivariate model (Table 2; Fig. 7c), fluvial fish richness was predicted to increase by 1-7 fluvial species, depending on the reach. The largest increases were expected in the upper river reaches and more moderate increases expected in the lower river reaches. Estimates of fish species richness for the species richness-drainage area model were $2 \times$ higher than the estimates from our multivariate models.
Thus, using only baseline conditions to inform management may not provide accurate predictions and realistic objectives for restoration in regulated rivers.

The fish assemblage in the Cheoah River did not respond as predicted given the relationships developed from the ELOHA framework. We attribute this to several factors that may have limited responses from the fish communities (later in the "Complications of Flow Restoration" section). Only one of the eight potential fluvial colonist species responded to the flow restoration. Black redhorse were found at multiple sites in the Cheoah River in 1993 and not again until 2006. Schools of black redhorse were observed during 2001 in Calderwood Reservoir near the mouth of the Cheoah River (Normandeau and others 2002b). We speculate that redhorse may have been 
Fig. 10 Point locations and two examples (photographs) of overturned instream vegetated islands of alder (A. glutinosa) resulting from a $226-\mathrm{m}^{3} \mathrm{~s}^{-1}$ flow event in the Cheoah River
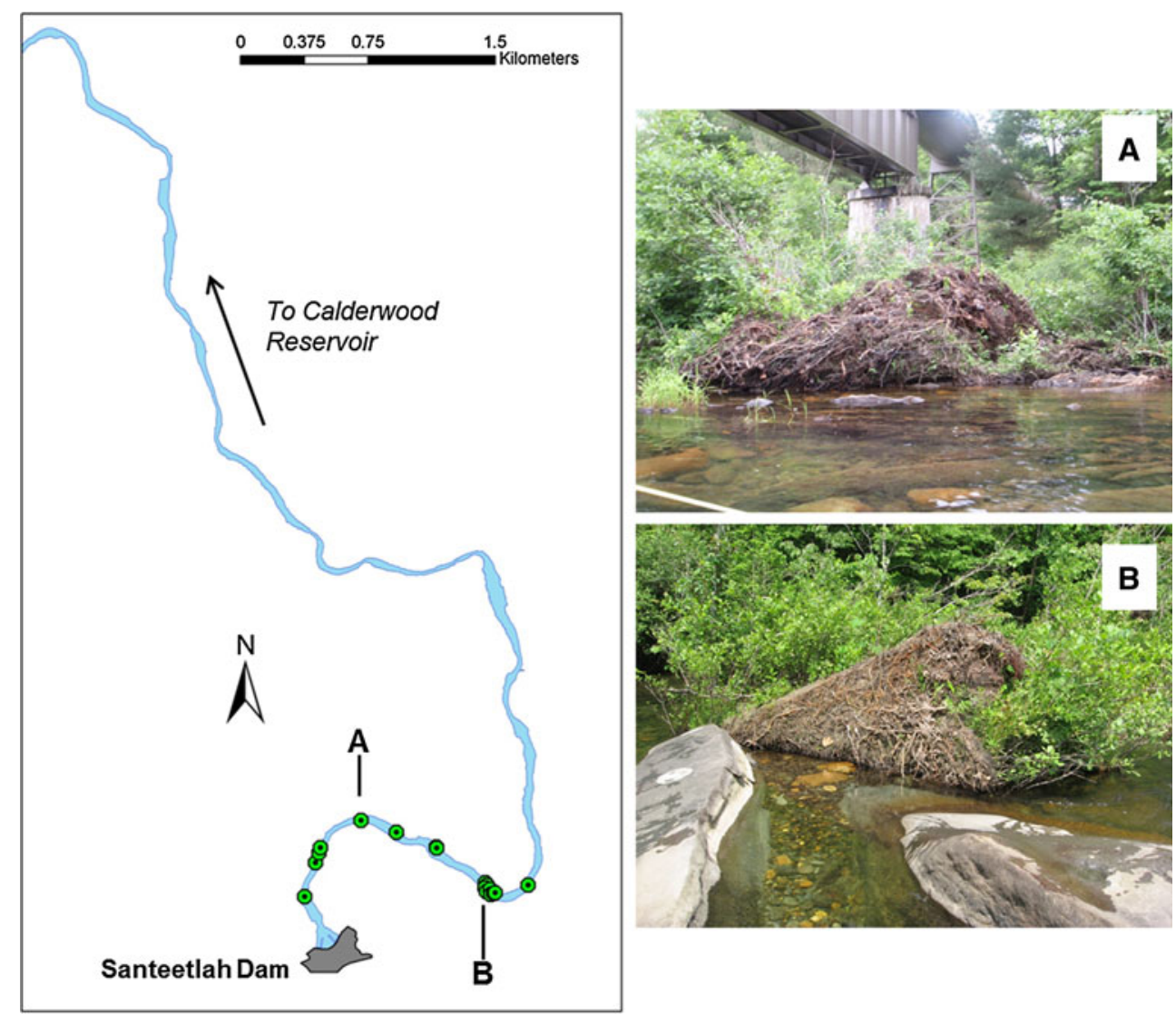

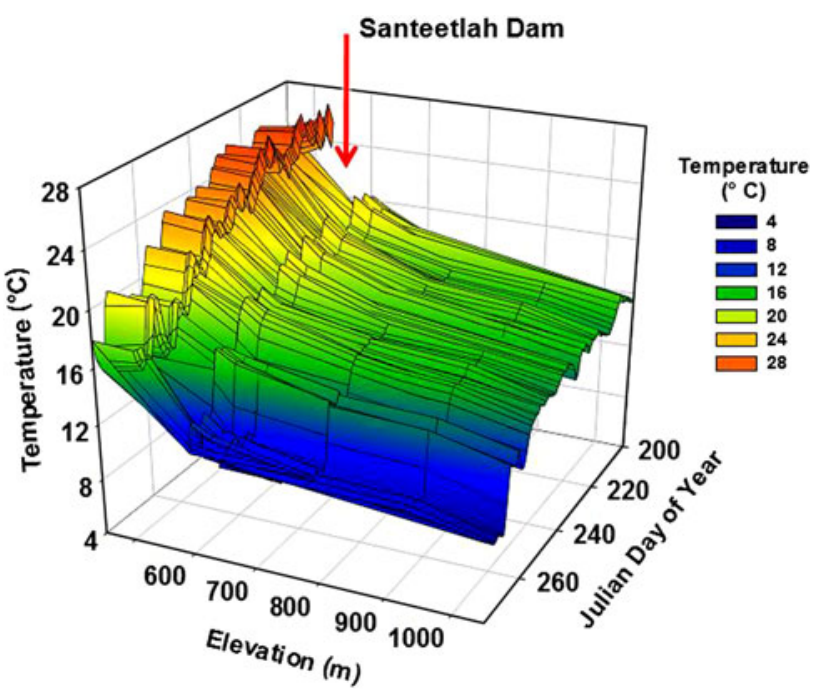

Fig. 11 Three-dimensional plot of the relationship between temperature, elevation, and Julian day of year in the Cheoah River and temperature effects caused by Santeetlah Dam

temporarily using the Cheoah as spawning grounds during conditions of elevated flow and following the increased minimum flow, they established permanent residency. Elevated water depths in pools may have provided adequate refuge and feeding habitat since all specimens have been observed in deeper pool habitats since 2006 .
Trends in occupancy suggested that the effects of the flow restoration were masked by a $425-\mathrm{m}^{3} \mathrm{~s}^{-1}$ flood event occurring on May 6, 2003. Calculations of flood-recurrence intervals from Santeetlah Dam spill records (1927 to current) suggest that a flood of similar magnitude was a $\geq 30$ year event. Five species showed declines following 2003. During 3-pass depletion efforts in 1993 and 1999, crews collected over 100 greenfin darters each year. However, immediately after the flood event in August 2003, similar sampling methodology yielded only 23 greenfin darters at the same sites $(>77 \%$ decline). Despite substantial increases in effort, Tuckasegee darters, a species endemic to the Little Tennessee basin, have displayed dramatic decreases in occupancy from pre-flood conditions (from $>0.60$ to 0.05 ). Unfortunately, our results also suggest that the flow restoration precipitated additional declines in Tuckasegee darter occupancy. Besides recolonization by black redhorse, occupancy for three species (whitetail shiner, smallmouth bass, and central stoneroller) increased following flow restoration, suggesting improved habitat conditions for these species.

Two limitations of our data were that fish sampling did not occur consistently with the same sites each year and there was unstandardized sampling among years. We insured that all sites and reaches were surveyed multiple times pre- and post-flow restoration. We also attempted to 
Table 6 Percent changes in the median particle size $\left(D_{50}\right)$ of pebble counts conducted at eight sites during 2002 and 2008 along the length of the Cheoah River

\begin{tabular}{llrrrr}
\hline Transect & $\begin{array}{l}\text { Distance } \\
\text { from Dam } \\
(\mathrm{km})\end{array}$ & $\begin{array}{l}\mathrm{D}_{50} \\
(\mathrm{~mm})\end{array}$ & $\begin{array}{l}\mathrm{D}_{50} \\
(\mathrm{~mm})\end{array}$ & \multicolumn{1}{l}{$\%$} & $\begin{array}{l}\text { change } \\
\text { chalue }\end{array}$ \\
\hline DC3 & 0.6 & 762 & 160 & -79 & $<0.001$ \\
DC7 & 2.3 & 1676.4 & 1000 & -40.35 & 0.991 \\
CY3 & 5.5 & 457.2 & 270 & -40.94 & 0.004 \\
CY8 & 6.7 & 304.8 & 160 & -47.51 & 0.064 \\
YD2 & 8.5 & 279.4 & 195 & -30.21 & 0.186 \\
YD7 & 9.5 & 914.4 & 350 & -61.72 & 0.005 \\
DM2 & 11 & 228.6 & 250 & 9.36 & 0.852 \\
DM5 & 12.5 & 203.2 & 257.5 & 26.72 & 0.028 \\
\hline
\end{tabular}

$P$ values represent results from Kruskal-Wallis tests

address potential uncertainties in occupancy estimates by accounting for detection probabilities $(P)$ values. Multiple surveys should be conducted each year to accurately account for variation in $P$ (MacKenzie and others 2006); however, methods are needed that can accommodate historical data lacking multiple surveys per year. Sampling effort was increased in 2004 by sampling at more sites and increased again in 2008-2009 by increasing the number of sites, using multiple methodologies, and surveying multiple times. Given increases in effort, declines in fish occupancy are presumed to be related to actual demographics and not an artifact of sampling design or effort.

\section{Riparian Ecology}

In comparison to the fish community, in-channel riparian coverage predictably decreased with increased flow magnitude and flooding. According to multivariate models, riparian coverage was predicted to decrease from 39-64 to 24-47\%, depending on reach. In regulated systems, diminished flow magnitudes and reduced peak floods substantially alter riparian communities (Auble and others 1994; Toner and Keddy 1997) by creating habitats less suitable to native riparian species that depend on hydrologic disturbances (Scott and others 1996, 1997). Documented overturned islands of alder vegetation and clear channels provide direct evidence that peak flows have removed vegetation and have inhibited reestablishment since 2005. Although several floods occurred in the Cheoah River in excess of $170 \mathrm{~m}^{3} \mathrm{~s}^{-1}$ during our study, we only observed overturned islands following a $232-\mathrm{m}^{3} \mathrm{~s}^{-1}$ flood event, which suggests that discharges of this magnitude may surpass critical shear thresholds needed for riparian removal.
Complications of Flow Restoration in Dam-Regulated Systems

Much of the existing relationship between flow and ecology is indirect (Poff and others 2010) and may involve multiple pathways including feedback loops (Anderson and others 2006). Unfortunately, dams tend to affect multiple factors simultaneously rather than individually. Thus, riverine communities may not respond predictably to flow restoration given the complexity of many confounding and interacting factors (e.g., temperature, sediment). We explore several factors that may have confounded the beneficial effects of flow restoration in the Cheoah River and provide additional insights into potential limitations of future applications in highly modified systems.

\section{Temperature}

Although the relationship between flow and temperature can be modeled accurately (Krause and others 2005), Olden and Naiman (2010) indicate that temperature is "a key, yet poorly acknowledged component of environmental flows." Temperatures below dams may impose such strong constraints on fish assemblages that flow restoration has little beneficial effects. For example, Krause and others (2005) found that stream temperatures remained well below suitable growth thresholds for brown trout, despite attempting a suite of alternative flow scenarios below a hypolimnetic-release hydropower dam.

Modeling temperature in conjunction with discharge variability is considered standard protocol for IFIM methods (Bovee and others 1998); however, temperature modeling was not considered during IFIM procedures in the Cheoah River (Normandeau and others 2002a). We observed a significant increase in average summer monthly temperatures following the flow restoration in 2005. Prior to flow restoration, elevated temperatures below Santeetlah Dam were likely the result of increased exposure to solar radiation due to shallow water depths, stagnant seepage, and increased residence time (Caissie 2006). Despite unnaturally high temperatures, cooler tributary inflow made up a larger proportion of flow in the Cheoah River prior to restoration. Releases of water from the surface of Santeetlah Reservoir increased thermal capacities, thereby diluting the effects of tributary inflow. In essence, the flow restoration amplified warm temperature conditions in the Cheoah River.

Evaluations of species distributions within the Cheoah River drainage provide additional evidence of a temperature problem. For example, the mottled sculpin is found in tributaries above and below Santeetlah Dam and in Calderwood 
Reservoir $\left(\leq 16^{\circ} \mathrm{C}\right)$, but is absent from the Cheoah River. Similarly, only one individual longnose dace was found directly below the entrance of Yellow Creek in the Cheoah River, but populations are found in all sampled tributaries above and below Santeetlah Dam. White sucker is the dominant fish in Calderwood Reservoir (Normandeau and others 2002b); however, it has never been observed in the Cheoah River. Maximum temperature tolerance for mottled sculpin is $30.9{ }^{\circ} \mathrm{C}$ (Kowalski and others 1978), whereas weekly average temperature thresholds reported for mottled sculpin, longnose dace, and white sucker are 24.3, 26.5, and $27.4{ }^{\circ} \mathrm{C}$, respectively (Eaton and Scheller 1996; Werlhy and others 2003). Summer temperatures in the Cheoah River reach in excess of $31{ }^{\circ} \mathrm{C}$. Although speculative, we suggest that some species may not inhabit the Cheoah River due to a temperature barrier. The absence of mottled sculpin may have implications that extend beyond the fish assemblage composition. The most suitable fish host for the federally endangered Appalachian elktoe is the Cottus species (sculpin) (Gordon and Moorman 2001; Keller and Augspurger 2005). Our results suggest that the temperature regime under current dam operations may indirectly limit the relict population of Appalachian elktoe in the Cheoah River.

\section{Substrate}

In rivers regulated by dams, reduced sediment supply results in a coarsening of the stream bed surface particles (Gordon and others 2004). Furthermore, riparian encroachment may intensify substrate conditions by locking up potentially mobile particles. We predicted that increased flows would increase the amount of finer substrates in the Cheoah river channel by the removal of encroached riparian vegetation and the inundation of new stream margins via erosive processes. Our data suggest that following flooding and flow restoration, textural fining occurred in the upstream reaches, whereas textural coarsening occurred in the downstream reaches. In the downstream reaches, increased flow magnitudes in association with high gradients increased shear stress on the stream bed, which may have offset any new deposits of material. If sediment supply remains constant, areas of active transport (erosion) may balance areas of deposition keeping total sediment transport constant within a river system (Gordon and others 2004).

Because of $>80$ years of being dewatered and regulated, substrate conditions in the Cheoah River are far coarser than that of surrounding river systems. In the Cheoah River, gravel particles $(8-64 \mathrm{~mm})$ and sand, as a percentage of streambed substrates, average less than half of that found in neighboring unregulated systems of a similar gradient and morphology (McManamay and others 2010). Tuckasegee darters are the only species in the Cheoah River which spawn on open sand, open fine gravel, or aquatic vegetation (Etnier and Starnes 1993). The remaining species spawn either by constructing nests in backwater habitats with fine sediment deposits or utilizing larger gravel and cobble in areas of moving current. Increasing flow magnitudes increases shear stress and transport capacities; thus, limited amounts of smallersized substrates in the Cheoah River could be eliminated with increases in flow. Jackson and Pringle (2010) argue that reducing flow magnitudes may be a better management action to prevent sediment starvation in streams. Because increased sediment supply does not accompany restored flow magnitudes, gravel additions may be required to offset increases in transport capacities following flow restoration (e.g., Kondolf and others 1996; Merz and Setka 2004). Gravel additions have shown success at enhancing spawning habitat for at least one gravel-spawning species in the Cheoah River (McManamay and others 2010), which provides additional evidence that regulated river restoration must be multi-faceted.

\section{Disturbance Regime}

In systems characterized by extreme physical disturbances, recolonization potential, reproductive success, and the ability to find habitat refugia will become more important in structuring fish communities than minor environmental fluctuations, such as changes in smaller-magnitude flows (Jackson and others 2001). Flood disturbances are generally considered beneficial to river systems by creating environments unfavorable to habitat generalists (Poff and others 1997; Bunn and Arthington 2002) and moderating diversity (Wootton and others 1996; Cardinale and others 2005). However, in highly fragmented systems, there may be negative consequences to reestablishing peak floods in degraded environments, especially if flows compromise existing habitats or provide pathways for non-native species invasions (Jackson and Pringle 2010). Trends in occupancy suggested that four fluvial fish species showed declines following the peak flood in 2003. Isolated populations of endemic species often times persist only on the basis of small patches of suitable habitat. Since large flood events have the potential to form habitats (Trush and others 2000), they also have the potential to destroy habitats necessary for population persistence.

Habitat connectivity and fragmentation determine fish recolonization potential (Jackson and others 2001) and fish population sustenance (Cooke and others 2005; Haponski and others 2007; Reid and others 2008; Kashiwagi and Miranda 2009). Large disturbances may push populations beyond recovery if there are no source populations to support recolonization. For example, Tuckasegee darters are not found in any tributaries that flow directly into the Cheoah River. In addition, only six species had direct 
access to potentially recolonize following flow restoration. The Cheoah River is among the most fragmented basins in the region, having only $14.8 \mathrm{~km}$ of continuous mainstem river habitats with few major tributaries. Other streams in the UTRB average $40 \mathrm{~km}$ of mainstem river habitat (range 6.3-102 km). In addition, the lower reach of the river has sustained high gradients and multiple cascades that drop in excess of $3 \mathrm{~m}$. Thus, the future persistence or non-persistence of some species in the Cheoah River may depend on species reintroduction and restoring other factors besides flow.

\section{Application of the ELOHA Process to Regulated Rivers}

Applying the ELOHA framework to restoration applications and individual case studies does not come without limitations. The main precepts of the ELOHA framework require compiling spatial, and to a lesser extent temporal, information on flow and ecology to develop and test hypotheses for a given region (Poff and others 2010). Environmental flow standards are then generalized from a body of information across multiple sites or multiple studies (e.g., Poff and Zimmerman 2010). Thus, the process of using ELOHA to inform management on a case-bycase basis may be limited given the scope and context of each river system. Regardless of the limitations, US dam facilities are typically managed on a site-by-site basis within the context of the following: dam operations, nearby dams, ecological and socio-economic needs, and physiochemical considerations (McCartney 2009). Given management complexity and stakeholder involvement, we do not envision that a framework will remove the need for individual case-by-case attention. In contrast, we envision that a framework(s) can be used to inform the relicensing process and individual case studies.

Another potential limitation of applying the ELOHA framework to restoration applications is that the temporal resolution of most case studies does not coincide with the temporal period of data underlying ELOHA relationships. For example, we evaluated ecological responses to restoration in the Cheoah River over a period of four years. However, the current ecological condition of the Cheoah River is an artifact of 80 years of flow diversion and river regulation. Most dams in the UTRB were constructed in the 1940s; hence, the majority of information supporting the ELOHA framework is from decades of river regulation. Thus, responses to restoration may not follow predictable patterns established by ELOHA.

The ELOHA framework uses baseline conditions to formulate univariate relationships between altered flow and ecology, which then inform the process of developing environmental flow standards (Fig. 1). Some aspects of riverine ecosystems, such as riparian ecology, may be adequately quantified by simple univariate relationships; thus, ELOHA may prove useful depending on the hydrologic context and taxa. However, we urge caution in using only patterns in hydrology to develop relationships between flow and ecology. In order to provide realistic expectations and guidelines for flow restoration in regulated systems, model building that incorporates flow and additional confounding variables, such as gradient and temperature, may be required. Within our analysis, multivariate models provided quantitative, predictive relationships and suggested that the exclusion of other variables would have dramatically decreased predictive capacity. We also urge caution in using only baseline conditions to develop flow-ecology relationships. Many times, baseline data are only available for smaller-sized streams representing a small range of the variability found in regulated systems. Using small sample sizes unrepresentative of the entire population of streams may lead to spurious conclusions. For example, if we had used only the available baseline data, our models would have dramatically overestimated fish richness values in regulated systems. Baseline data for large river systems may need to be accurately reconstructed. Again, model building may help to avoid these pitfalls.

Overall, the ELOHA process provided a robust framework to build and organize hydrologic information, develop hydrologic foundations, and place flow-ecology relationships into appropriate contexts. Although the riparian community responded to flow restoration as predicted, the fish community showed little response, quite possibly due to a multitude of interacting factors. It is unlikely that all interactions among flow, temperature, morphology, and preexisting disturbance regimes can be addressed, much less modeled, without uncertainty prior to implementing environmental flow standards. Although we do not expect that all observations in the Cheoah River are broadly applicable, our case study highlights the importance of adaptive management (AM), which is conceptualized as feedback loops between monitoring and implementing environmental flow standards within the ELOHA framework (Fig. 1). We believe this is one of the most important aspects of environmental flow management and the ELOHA framework. AM is a cycle of hypothesis development, management implementation, documented learning, and hypotheses regeneration (Holling 1978; Walters 1986). Thus, environmental flow restoration should be implemented as ecosystem-scale experiments to advance the understanding of river function and then adapted based on findings (Poff and others 2003). The Australians have been successful at using AM frameworks in developing and refining environmental flow standards for some time (Maier and others 2001; King and others 2010; Watts and others 2010) with other countries close 
behind (Arthington and others 2003). Within the US, obstacles to AM approaches in relation to environmental flows include socio-political controversy over economic trade-offs, unwillingness of stakeholders to embrace risk, policy standards by regulatory agencies, and financial expense (Richter and others 2006); however, AM approaches within high-profile situations are being used within the US (CGCMR and others 1999; Richter and others 2006; Konrad and others 2012). Nonetheless, AM will continue to be a major pathway of successfully reinstituting environmental flows in regulated rivers, thereby increasing the value of information learned from case studies.

Acknowledgments This work was funded by the Cheoah Fund Board, a multi-agency collaboration among Alcoa Power, the USDA Forest Service, the US Fish and Wildlife Service, the North Carolina
Wildlife Resources Commission, the NC Division of Water Resources-DENR, and other grants provided by the USDA Forest Service. Funding was also provided by the Sigma Xi Grants-In-Aid of Research Program. We thank Mark Cantrell, Chris Goodreau, Steve Fraley, Steve Reid, Jim Mead, Rick Simmons, Paul Leonard, and Andrew Bearden for providing reports, summaries, and data. Suggested revisions on earlier versions of this paper were provided by Mark Cantrell, Paul Angermeier, Emmanuel Frimpong, and Tess Wynn. In addition, comments provided by five anonymous reviewers substantially improved this paper. We also extend gratitude to Tyler Young, Toby Coyner, David Belkoski, Travis Patton, Jason Emmel, McKeever Henley, and Adam Hart for their assistance with field work.

\section{Appendix}

See Table 7.

Table 7 List of fish species as residents, occasional, potential colonists, and reintroduced in the Cheoah River from 1993 to 2009 and in tributaries below Santeetlah Dam, Calderwood Reservoir (mouth of Cheoah), and tributaries above Santeetlah Dam

\begin{tabular}{|c|c|c|c|c|c|c|c|c|c|c|c|c|}
\hline \multirow[t]{4}{*}{ Common Name } & \multirow[t]{2}{*}{ Scientific Name } & \multirow{2}{*}{$\begin{array}{c}1993 \\
\text { P }\end{array}$} & \multirow{2}{*}{$\begin{array}{c}1999 \\
\text { P }\end{array}$} & \multirow{2}{*}{$\begin{array}{c}2003 \\
\text { F }\end{array}$} & \multirow{2}{*}{$\begin{array}{c}2004 \\
\text { F }\end{array}$} & \multirow{2}{*}{$\begin{array}{c}2005 \\
\text { F }\end{array}$} & \multirow{2}{*}{$\begin{array}{c}2006 \\
\text { FR }\end{array}$} & \multirow{2}{*}{$\begin{array}{c}2008 \\
\text { FR }\end{array}$} & \multirow{2}{*}{$\begin{array}{c}2009 \\
\text { FR }\end{array}$} & \multirow[t]{2}{*}{ Tributaries } & \multirow[t]{2}{*}{ Calderwood } & \multirow[t]{2}{*}{ Above Dam } \\
\hline & & & & & & & & & & & & \\
\hline & Total Species & 13 & 11 & 13 & 14 & 16 & 11 & 18 & 18 & & & \\
\hline & Fluvial Species & 11 & 9 & 10 & 10 & 11 & 10 & 13 & 13 & & & \\
\hline \multicolumn{13}{|c|}{ Residents and Occasional } \\
\hline Rock bass* & Amploplites rupestris & $\bullet$ & - & - & - & - & - & - & - & 0 & - & - \\
\hline Central stoneroller* & Campostoma anomalum & 0 & 0 & - & - & - & 0 & - & - & - & - & $\bullet$ \\
\hline Whitetail shiner* & Cyprinella galactura & $\bullet$ & - & - & - & $\bullet$ & $\bullet$ & - & - & 0 & - & 0 \\
\hline Tuckasegee darter & Etheostoma blerniodes gutselli & $\bullet$ & - & - & - & • & $\bullet$ & - & - & 0 & - & - \\
\hline Greenfin darter* & Etheostoma chlorobranchium & - & - & - & - & $\bullet$ & $\bullet$ & - & • & 0 & 0 & - \\
\hline Northern hog sucker* & Hypentelitum nigricans & - & - & - & - & - & - & - & - & - & $\bullet$ & $\bullet$ \\
\hline Green sunfish & Lepomis cyanellus & 0 & 0 & 0 & $\bullet$ & $\bullet$ & 0 & 0 & $\bullet$ & $\mathrm{O}$ & 0 & $\bullet$ \\
\hline Bhegill & Lepomis macrochirus & 0 & 0 & - & - & $\bullet$ & 0 & - & $\bullet$ & 0 & $\bullet$ & $\bullet$ \\
\hline Warpaint shiner* & Lwoillus coccogenis & - & - & - & - & $\bullet$ & $\bullet$ & $\bullet$ & $\bullet$ & 0 & - & $\bullet$ \\
\hline Smallmouth bass" & Micropterus dolomieu & - & - & - & - & - & - & - & - & 0 & $\bullet$ & 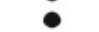 \\
\hline Spotted bass & Micropterus punctatus & 0 & 0 & 0 & 0 & - & O & 0 & 0 & 0 & 0 & 0 \\
\hline Largemouth bass & Micropterus salmoides & 0 & 0 & - & - & 0 & 0 & - & - & 0 & $\bullet$ & 0 \\
\hline River chub* & Nocomis micropogon & $\bullet$ & - & - & - & - & $\bullet$ & - & - & $\bullet$ & - & - \\
\hline Rainbow trout & Onchorynchus mykiss & $\bullet$ & $\bullet$ & - & - & $\bullet$ & - & - & - & - & 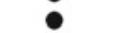 & 0 \\
\hline Tangerine darter* & Percina aurantiaca & - & $\bullet$ & - & - & - & - & - & $\bullet$ & 0 & 0 & $\bullet$ \\
\hline Fathead minnow & Pimephales promelas & 0 & 0 & 0 & 0 & - & 0 & 0 & 0 & 0 & 0 & $\bullet$ \\
\hline Flathead catfish & Pylodictis olivaris & $\bullet$ & $\bullet$ & 0 & 0 & 0 & 0 & sin. & 0 & 0 & 0 & $\bullet$ \\
\hline Brown trout & Salmo trutta & - & 0 & 0 & 0 & 0 & 0 & - & ow & - & - & $\bullet$ \\
\hline Walleye & Sander vitreum & 0 & O & 0 & 0 & 0 & 0 & on & 0 & 0 & - & - \\
\hline \multicolumn{13}{|c|}{ Potential Fluvial Colonists } \\
\hline Longnose dace* & Rhinichthys cataractae & 0 & 0 & 0 & 0 & 요 & 0 & an & a & - & 0 & $\bullet$ \\
\hline Black rechorse* & Moxostoma diuquesnei & - & 0 & 0 & 0 & 0 & - & - & - & 0 & - & - \\
\hline Blacknose dace* & Rhinichthys atratulus & 0 & 0 & 0 & 0 & 0 & 0 & 0 & 0 & - & 0 & - \\
\hline White sucker* & Catostomus commersonii & 0 & 0 & 0 & 0 & 0 & 0 & 0 & 0 & 0 & - & 0 \\
\hline Tennessee shiner* & Notropis leucioaius & 0 & 0 & 0 & 0 & 0 & 0 & 0 & 0 & 0 & 0 & $\bullet$ \\
\hline Mottled sculpin* & Cottus bairdii & 0 & 0 & 0 & 0 & 0 & 0 & 0 & 0 & - & - & - \\
\hline Creek chub* & Semotilus atromaculatus & 0 & 0 & 0 & 0 & 0 & 0 & 0 & 0 & $\bullet$ & 0 & 0 \\
\hline Rebreast sunfish* & Lepomis auritus & 0 & 0 & O & 0 & 0 & 0 & 0 & 0 & O & 0 & • \\
\hline \multicolumn{13}{|l|}{ Reintroduced species } \\
\hline Wounded darter* & Etheostoma vulneratum & 0 & 0 & 0 & 0 & 0 & O & 0 & ( & 0 & 0 & 0 \\
\hline Spotfin chub* & Cyprinella monocha & 0 & 0 & 0 & 0 & 0 & 0 & 0 & () & 0 & 0 & 0 \\
\hline
\end{tabular}

Dark circles represent presence whereas open circles represent absence. Half circles represent unknown status. Shaded cells represent occasions in which only one representative individual was found

$P, F$, and $F R$ represent pre-flood, post-flood, and restoration post-flood

* Fluvial species 


\section{References}

Abell R, Theime ML, Revenga C, Bryer M, Kottelat M, Bogutskya N, Coad B, Mandrak N, Contreras Balderas S, Bussing W, Stiassny MLJ, Skelton P, Allen GR, Unmack P, Neseka A, Ng R, Sindorf N, Robertson J, Armiho E, Higgins JV, Heibel TJ, Wikramanayake E, Olson D, López HL, Heis RE, Lundberg JG, Sabaj Pérez MH, Petry P (2008) Freshwater ecoregions of the world: a new map of biogeographic units for freshwater biodiversity conservation. BioScience 58:403-414

Anderson MJ (2001) A new method for non-parametric multivariate analysis of variance. Austral Ecol 26:32-46

Anderson KE, Paul AJ, McCauley E, Jackson LJ, Post JR, Nisbet RM (2006) Instream flow needs in streams and rivers: the importance of understanding ecological dynamics. Front Ecol 4:309-318

Angermeier PL, Schlosser IJ (1989) Species-area relationship for stream fishes. Ecology 70:1450-1462

Arthington AH, Rall JL, Kennard MJ, Pusey BJ (2003) Environmental flow requirements of fish in Lesotho rivers using the DRIFT methodology. River Res Appl 19:641-666

Arthington AH, Bunn SE, Poff NL, Naiman RJ (2006) The challenge of providing environmental flow rules to sustain river systems. Ecol Appl 16:1311-1318

Auble GT, Friedman JM, Scott ML (1994) Relating riparian vegetation to present and future streamflows. Ecol Appl 4:544-554

Barinaga M (1996) A recipe for recovery? Science 273:1648-1650

Bisson PA, Montgomery DR, Buffington JM (2006) Valley segments, stream reaches, and channel units. In: Hauer FR, Lamberti GA (eds) Methods in stream ecology, 2nd edn. Academic Press, Burlington, pp 23-49

Bovee KD, Lamb BL, Bartholow JM, Stalnaker CB, Taylor J, Henriksen J (1998) Stream habitat analysis using the instream flow incremental methodology. U.S. Geological Survey Information and Technology Report 1998-0004

Brandt SA (2000) Classification of geomorphological effects downstream of dams. Catena 40:375-401

Bunn SE, Arthington AH (2002) Basic principles and ecological consequences of altered flow regimes for aquatic biodiversity. Environ Manag 30:492-507

Burnham KP, Anderson DR (2004) Multimodel inference: understanding AIC and BIC in model selection. Sociol Method Res 33:261-304

Caissie D (2006) The thermal regime of rivers: a review. Fresh Biol 51:1389-1406

Cardinale BJ, Palmer MA, Ives AR, Brooks SS (2005) Diversityproductivity relationships in streams vary as a function of the natural disturbance regime. Ecology 86:716-726

CGCMR (Committee on the Grand Canyon Monitoring and Research), Water Science and Technology Board, Commission on Geoscience, Environment and Resources, National Research Council (1999) Downstream: adaptive management of Glen Canyon Dam and the Colorado River ecosystem. National Academy Press, Washington

Colwell RK (1974) Predictability, constancy, and contingency of periodic phenomena. Ecology 55:1148-1153

Cooke SJ, Bunt CM, Hamilton SJ, Jennings CA, Pearson MP, Cooperman MS, Markle DF (2005) Threats, conservation strategies, and prognosis for suckers (Catostomidae) in North America: insights from regional case studies of a diverse family of non-game fishes. Biol Conserv 121:317-331

Dieterman DJ, Galat DL (2004) Large-scale factors associated with Sicklefin Chub distribution in the Missouri and lower Yellowstone rivers. Trans Am Fish Soc 133:577-587

Dilts E, Bearden A, Leonard P (2003) Tapoco Hydroelectric project technical memorandum: Cheoah River substrate supplementation program — baseline substrate assessment. Report of Entrix Consultants to U.S.Forest Service, Asheville

Eaton JG, Scheller RM (1996) Effects of climate warming on fish thermal habitat in streams of the United States. Limnol Oceanogr 41:1109-1115

Etnier DA, Starnes WC (1993) The fishes of Tennessee. University of Tennessee Press, Knoxville

Fausch KD, Torgersen CE, Baxter CV, Li HW (2002) Landscapes to riverscapes: bridging the gap between research and conservation of stream fishes. BioScience 52:483-498

FERC (Federal Energy Regulation Commission) (2005) Order approving settlement and issuing new license. FERC, Project No. 2169-020, Washington, DC

FERC (Federal Energy Regulation Commission) (2006) Order approving Cheoah River bypassed reach gravel enhancement plan. FERC, Project No. 2169-036, Washington, DC

Frimpong EA, Angermeier PL (2009) FishTraits: a database of ecological and life-history traits of freshwater fishes of the United States. Fish 34:487-495

Giraudox P (2012) Package 'pgirmess'. Reference manual. http:// cran.r-project.org/web/packages/pgirmess/pgirmess.pdf. Accessed 15 July 2012

Gordon ME, Moorman JR (2001) Glochidial host for Alasmidonta raveneliana (Bivalvia: Unionidae). Malacol Rev 31:33-35

Gordon ND, McMahon TA, Finlayson BL, Gippel CJ, Nathan RJ (2004) Stream hydrology. An introduction for ecologists, 2nd edn. Wiley, West Sussex

Haponski AE, Marth TA, Stepien CA (2007) Genetic divergence across a low-head dam: a preliminary analysis using logperch and greenside darters. J Gt Lake Res 33:117-126

Harrelson CC, Rawlins CL, Potyondy JP (1994) Stream channel reference sites: an illustrated guide to field technique. USDA Forest Service, General Technical Report RM-245, Fort Collins

Henriksen JA, Heasley J, Kennen JG, Nieswand S (2006) Users' manual for the hydroecological integrity assessment process software (including the New Jersey Assessment Tools). US Geological Survey Report 2006-1093

Holling CS (1978) Adaptive environmental assessment and management. Wiley, New York

Jackson CR, Pringle CM (2010) Ecological benefits of reduced hydrologic connectivity in intensively developed landscapes. BioScience 60:37-46

Jackson DA, Peres-Neto PR, Olden JD (2001) What controls who is where in freshwater fish communities-the roles of biotic, abiotic and spatial factors. Can J Fish Aquat Sci 58:157-170

Karr JR (1981) Assessment of biotic integrity using fish communities. Fish 6:21-27

Karr JR, Fausch KD, Angermeier PL, Yant PR, Schlosser IJ (1986) Assessing biological integrity in running waters: a method and its rationale. Illinois Natural History Survey Special Publication 5, Champaign

Kashiwagi MT, Miranda LE (2009) Influence of small impoundments on habitat and fish communities in headwater streams. Southeast Nat 8:23-36

Keller AE, Augspurger T (2005) Toxicity of fluoride to the endangered unionid mussel, Alasmidonta raveneliana, and surrogate species. Bull Environ Contam Toxicol 74:242-249

Kendy E, Apse C, Blann K (2012) A practical guide to environmental flows for policy and planning with nine case studies in the United States. The Nature Conservancy. http://conserveonline. org/workspaces/eloha/documents/template-kyle. Accessed 18 July 2012

Kennard MJ, Pusey BJ, Olden JD, Mackay SJ, Stein JL, Marsh N (2010) Classification of natural flow regimes in Australia to support environmental flow management. Fresh Biol 55:171-193 
King AJ, Ward KA, O'Connor P, Green D, Tonkin Z, Mahoney J (2010) Adaptive management of an environmental watering event to enhance native fish spawning and recruitment. Fresh Biol 55:17-31

Knight RR, Gregory MB, Wales AK (2008) Relating streamflow characteristics to specialized insectivores in the Tennessee River Valley: a regional approach. Ecohydrology 1:394-407

Kondolf GM, Vick JC, Ramirez TM (1996) Salmon spawning habitat rehabilitation on the Merced River, California: an evaluation of project planning and performance. Trans Am Fish Soc 125: 899-912

Konrad CP, Warner A, Higgins JV (2012) Evaluating dam reoperation for Fresh conservation in the sustainable rivers project. River Res Appl 28:777-792

Kowalski KT, Schubauer JP, Scott CL, Spotila JK (1978) Interspecific and seasonal differences in the temperature tolerance of stream fish. J Therm Biol 3:105-108

Krause CW, Newcomb TJ, Orth DJ (2005) Thermal habitat assessment of alternative flow scenarios in a tailwater fishery. River Res Appl 21:581-593

Lindsey J (2012) Statistical libraries: nonlinear regression and repeated measurements. http://www.commanster.eu/rcode.html. Accessed 10 July 2012

MacKenzie DI, Nichols JD, Royle JA, Pollock KH, Bailey LL, Hines JE (2006) Occupancy estimation and modeling: inferring patterns and dynamics of species occurrence. Academic Press, Boston

Maier HR, Burch MD, Bormans M (2001) Flow management strategies to control blooms of the cyanobacterium, Anabaena circinalis, in the River Murray at Morgan, South Australia. Regul River Res Manag 17:637-650

McCargo J, Peterson J (2010) An evaluation of the influence of seasonal base flow and geomorphic stream characteristics on Coastal Plain stream fish assemblages. Trans Am Fish Soc 139:29-48

McCartney M (2009) Living with dams: managing the environmental impacts. Water Pollut 11:121-139

McCully P (1996) Silenced rivers the ecology and politics of large dams. Zed Books, London

McManamay RA, Orth DJ, Dolloff CA, Cantrell MA (2010) Gravel addition as a habitat restoration technique for tailwaters. $\mathrm{N}$ Am J Fish Manag 30:1238-1257

McManamay RA, Orth DJ, Dolloff CA (2012a) Revisiting the homogenization of dammed rivers in the southeastern US. J Hydrol 424-425:217-237

McManamay RA, Orth DJ, Dolloff CA, Frimpong EA (2012b) A regional classification of unregulated streamflows: spatial resolution and hierarchical frameworks. River Res Appl 28:1019-1033

Menhinick EF (1991) The fresh fishes of North Carolina. North Carolina Wildlife Resources Commission, Raleigh

Merz JE, Setka JD (2004) Evaluation of a spawning habitat enhancement site for Chinook salmon in a regulated California River. N Am J Fish Manag 24:397-407

NatureServe (2010) Digital distribution maps of the Freshwater fishes in the conterminous United States. Version 3.0. http://www.nat ureserve.org/getData/fishMaps.jsp. Accessed 15 Nov 2011

Normandeau et al (2001) Cheoah River temperature analysis supplement to Flow Regime and Aquatic Habitat Assessment for the Cheoah River, Part II. Report to Alcoa Power Generating, Inc., TN, December 2001

Normandeau et al (2002a) Flow regime and aquatic habitat assessment for the Cheoah River downstream of Santeetlah Reservoir, North Carolina. Part 1. Report to Alcoa Power Generating, Inc, TN, April 2002

Normandeau et al (2002b) Final report for aquatic study 1: Reservoir and Tailwater Fishery Assessment, Tapoco hydroelectric project
FERC No. 2169. Report to Alcoa Power Generating, Inc., TN, January 2002

Olden JD, Naiman RJ (2010) Incorporating thermal regimes into environmental flows assessments: modifying dam operations to restore Freshwater ecosystem integrity. Fresh Biol 55:86-107

Palmer MW, White PS (1994) Scale dependence and the species-area relationship. Am Midl Nat 144:717-740

Peoples BK, Frimpong EA (2011) Among-pass, interregional, and single- versus multiple-season comparisons of detection probabilities of stream fishes. Trans Am Fish Soc 140:67-83

Petty MA, Ruble CL, Rakes PL, Shute JK (2011) Propagation and reintroduction of wounded darters, Etheostoma vulneratum, in the Cheoah River, North Carolina. Final report to NC Division of Water Resources (Contract No. DENR 3481), Cheoah Fund, Raleigh, NC, January 4, 2011

Poff NL (1996) A hydrogeography of unregulated streams in the United States and an examination of scale-dependence in some hydrological descriptors. Fresh Biol 36:71-91

Poff NL, Ward JV (1989) Implications of streamflow variability and predictability for lotic community structure-a regional-analysis of streamflow patterns. Can J Fish Aquat Sci 46:1805-1818

Poff NL, Zimmerman JZH (2010) Ecological responses to altered flow regimes: a literature review to inform the science and management of environmental flows. Fresh Biol 55:194-205

Poff NL, Allan JD, Bain MB, Karr JR, Prestegaard KL, Richter BD, Sparks RE, Stromberg JC (1997) The natural flow regime: a paradigm for river conservation and restoration. BioScience 47:769-784

Poff NL, Allan JD, Palmer MA, Hart DD, Richter BD, Arthington AH, Rogers KH, Meyer JL, Stanford JA (2003) River flows and water wars: emerging science for environmental decisionmaking. Front Ecol Environ 1:298-306

Poff NL, Olden JD, Merritt DM, Pepin DM (2007) Homogenization of regional river dynamics by dams and global biodiversity implications. Proc Natl Acad Sci USA 104:5732-5737

Poff NL, Richter BD, Arthington AH, Bunn SE, Naiman RJ, Kendy E, Acreman M, Apse C, Bledsoe BP, Freeman MC, Henriksen J, Jacobson RB, Kennen JG, Merritt DM, O'Keeffe JH, Olden JD, Rogers K, Tharme RE, Warner A (2010) The ecological limits of hydrologic alteration (ELOHA): a new framework for developing regional environmental flow standards. Fresh Biol 55: $147-170$

R2 (R2 Resource Consultants, Inc) (2003) Tapoco Hydroelectric Project Technical Memorandum: Cheoah River substrate supplementation. Report to U.S. Forest Service, Asheville, NC

Rakes PL, Shute JR, Shute PW (1999) Reproductive behavior, captive breeding, and restoration ecology of endangered fishes. Environ Biol Fish 55:31-42

Reid SM, Mandrak NE, Carl LM, Wilson CC (2008) Influence of dams and habitat condition on the distribution of redhorse (Moxostoma) species in the Grand River watershed, Ontario. Environ Biol Fish 81:111-125

Richhter BD, Baumgartner JV, Powell J, Braun DP (1996) A method for assessing hydrologic alteration within ecosystems. Conserv Biol 10:1163-1174

Richter BD (2011) River and Lakes-Global Fresh Program: improving dams for people and nature. The Nature Conservancy. http:// www.nature.org/ourinitiatives/habitats/riverslakes/global-Freshprogram-improving-dams-for-people-and-nature.xml. Accessed 31 Mar 2011

Richter BD, Warner AT, Meyer JL, Kim Lutz (2006) A collaborative and adaptive process for developing environmental flow recommendations. River Res Appl 22:297-318

Richter BD, Davis MM, Apse C, Konrad C (2012) A presumptive standard for environmental flow protection. River Res Appl 28: $1312-1321$ 
Ries KG, Crouse MY (2002) The National Flood Frequency Program, Version 3: a computer program for estimating magnitude and frequency of floods for ungaged sites, 2002. U.S. Geological Survey Water-Resources Investigations Report 02-4168, Reston, VA

Roni P, Beechie TJ, Bilby RE, Leonetti FE, Pollock MM, Pess GR (2002) A review of stream restoration techniques and a hierarchical strategy for prioritizing restoration in Pacific northwest watersheds. N Am J Fish Manag 22:1-20

Roni P, Hanson K, Beechie T (2008) Global review of the physical and biological effectiveness of stream habitat rehabilitation techniques. N Am J Fish Manag 28:856-890

Rosenberg DM, McCully P, Pringle CM (2000) Global-scale environmental effects of hydrological alterations: introduction. BioScience 50:746-751

Rosgen DL (1994) A classification of natural rivers. Catena 22: 169-199

Scott ML, Friedman JM, Auble GT (1996) Fluvial patterns and establishment of bottomland trees. Geomorphology 14:327-339

Scott ML, Auble GT, Friedman JM (1997) Flood dependency of cottonwood establishment along Missouri River, Montana, USA. Ecol Appl 7:677-690

Sowa SP, Annis G, Morey ME, Diamond DD (2007) A gap analysis and comprehensive conservation strategy for riverine ecosystems of Missouri. Ecol Monogr 77:301-334

Stevens MHH, Okasanen J (2012) Permutation Multivariate Analysis of Variance. adonis\{vegan\}. http://cc.oulu.fi/ jarioksa/softhelp/ vegan/html/adonis.html. Accessed 11 July 2012

Stewart-Oaten A, Murdoch WM, Parker KR (1986) Environmental impact assessment: "pseudoreplication" in time? Ecology 67:929-940

Tear TH, Kareiva P, Angermeier PL, Comer P, Czech B, Kautz R, Landon L, Mehlman D, Murphy K, Ruckelshaus M, Scott JM, Wilhere G (2005) How much is enough? The recurrent problem of setting measurable objectives in conservation. BioScience $55: 835-849$

Tharme RE (2003) A global perspective on environmental flow assessment: emerging trends in the development and application of environmental flow methodologies for rivers. River Res Appl 19:397-441

Toner M, Keddy P (1997) River hydrology and riparian wetlands: a predictive model for ecological assembly. Ecol Appl 7:236-246

Trush WJ, McBain SM, Leopold LB (2000) Attributes of an alluvial river and their relation to water policy and management. Proc Natl Acad Sci USA 97:11858-11863

Underwood AJ (1994) On beyond BACI: Sampling designs that might reliably detect environmental disturbances. Ecol Appl $4: 3-15$

USACE (US Army Corps of Engineers) (2011) National inventory of dams. US Army Corps of Engineers. https://nid.usace.army.mil. Accessed 24 June 2011

USFWS (U.S. Fish and Wildlife Service) (1994) Endangered and threatened wildlife and plants; Appalachian elk toe determined to be an endangered species. Fed Reg 59:60324-60334

USGS (US Geological Survey) (2012) PRESENCE 5.3 and GENPRES software. Patuxent Wildlife Research Center. http://www. mbr-pwrc.usgs.gov/software/presence.html. Accessed 7 Nov 2012

Vitousek PM, Mooney HA, Lubchenco J, Melillo JM (1997) Human domination of Earth's ecosystems. Science 277:494-499

Walters C (1986) Adaptive management of renewable resources. Blackburn Press, New Jersey

Watts RJ, Ryder DS, Allan C, Commens S (2010) Using river-scale experiments to inform variable releases from large dams: a case study of emergent adaptive management. Mar Fresh Res 61:786-797

Wehrly KE, Wiley MJ, Seelbach PW (2003) Classifying regional variation in thermal regime based on stream fish community patterns. Trans Am Fish Soc 132:18-38

Wollock DM, Winter TC, McMahon G (2004) Delineation and evaluation of hydrologic-landscape regions in the United States using geographic information system tools and multivariate statistical analyses. Environ Manag 34:71-88

Wolman MG (1954) A method of sampling coarse river-bed material. Trans Am Geophys Union 35:951-956

Wootton JT, Parker MS, Power ME (1996) Effects of disturbance on river food webs. Science 273:1558-1561 